\title{
INCIDENCIA JURÍDICA DE LA LAICIDAD DEL ESTADO EN LA SOCIEDAD PLURAL*
}

\author{
LEGAL INCIDENCE OF THE LAITY OF THE STATE IN THE \\ PLURAL SOCIETY
}

\begin{abstract}
Arturo Calvo Espiga*
RESUMEN: Laicidad y pluralismo son categorías fundamentales y claves a la hora de articular las relaciones que el Estado ha de mantener con el fenómeno religioso, en su más pleno sentido, tal y como aparece en nuestras sociedades democráticas occidentales. La laicidad, en esta reflexión, se asume como característica, categoría, actitud o límite del Estado y de su propia actividad; el pluralismo se considera como característica y propiedad esencial de nuestras sociedades contemporáneas y como valor ciudadano. Se pretende en esta aportación clarificar la relación que existe entre la laicidad de los Estados y las sociedades abiertas y plurales, en cuanto característica esencial de la sociedad justa. Las sociedades democráticas, como tales, no son ni laicas, ni confesionales, sino plurales y libres, tanto desde el punto de vista religioso como ideológico. Solo en los totalitarismos, desde los imperios romano y orientales hasta nuestros días, cabe plantear la existencia de sociedades confesionales, monistas, bien de carácter religioso, antirreligioso o ideológico. La laicidad del Estado es, sobre todo, respeto y garantía de desarrollo y promoción de la pluralidad social. Solo así se podrá conseguir la justicia en la libertad no discriminatoria. Por ello, los aparatos estatales deberán abstenerse de cualquier intervención favorecedora de una determinada ideología o ideal religioso y evitar, en lógica consecuencia, que la propia laicidad se convierta en ideología de Estado, así como de la propia conformación de la sociedad.
\end{abstract}

Palabras clave: pluralismo, laicidad, libertad religiosa, derechos fundamentales, democracia.

ABSTRACT: Laity, pluralism and freedom are basic and key categories when joint the relationship or relationships that the State has to keep with the religious phenomenon, in its more full meaning, just as it appears in our democratic western societies. The laity, in this reflection, is assumed as a characteristic, category, attitude or limit to the State and its own activity; pluralism as a characteristic is considered an essential property of our contemporary societies and as citizen value. It is expected in this contribution to clarify the relationship between the laity of the States and the open and plural societies, as an essential characteristic of the just society. Democratic societies, as such, are neither lay nor denominational, but plurals and free, both from the religious point of view as ideological. Only in the totalitarianisms, from Roman and Eastern empires until our days, fits to pose the existence of denominational, unitary, religious character, antireligious or ideological societies. The laity of the State is, above all, guarantee for development and promotion of the social plurality. Only then, justice in a non discriminatory freedom can be achieved. For this reason, state apparatus should abstain of any intervention to promote a certain ideology or religious ideal, and to avoid, in logical consequence, that the laity becomes ideology of State or a first determinant of the society. 
Key words: pluralism, laity, religious freedom, fundamental rights, democracy.

\section{PLANTEAMIENTO}

El binomio con que se inicia el título de esta aportación, laicidadpluralidad, tiene, en su formulación, no solo una intención descriptiva o enunciativa, sino, principal e intencionalmente un sentido dialógico o dialéctico, tal como se desprende de la segunda parte del propio encabezamiento. Asumimos el término dialéctico en el sentido de la argumentación que se articula y ordena a través de un discurso lógico o mediante el contraste de varios discursos que racional y razonadamente tienden al descubrimiento de la verdad. El respeto y promoción del pluralismo social presupone, al menos en nuestras sociedades democráticas occidentales, la laicidad del Estado como garantía política y jurídica del pleno ejercicio de los derechos fundamentales. Por otra parte, solo se podrá hablar de laicidad auténtica en la medida que sirva de medio para profundizar el pluralismo social; o lo que es lo mismo, siempre que el Estado laico procure la construcción de una sociedad justa en la que igualdad y libertad se integren y complementen. Planteamiento que, evidentemente, requiere el marco de sociedades abiertas en las que se acepten la libertad y la justicia como valores o principios fundamentales de las mismas, pues solo en la justicia y en la libertad puede hacerse efectiva la verdadera igualdad.

\section{LA SOCIEDAD PLURAL}

Desde la perspectiva histórica, la idea, o si se prefiere el concepto de pluralidad o pluralismo en su raíz, no el término que se formulará mucho más tarde, puede considerarse implícita en la propia noción de tolerancia, así como en el proceso de su gradual y progresiva aceptación, sobre todo, a partir de la segunda mitad del siglo XVII ${ }^{1}$. Intrínsecamente conectados, el pluralismo presupone la existencia previa de la tolerancia, por lo que un pluralismo intolerante sería un falso pluralismo; si bien, entre ellos existe una importante diferencia, pues mientras la tolerancia se limita a respetar los valores ajenos, el pluralismo afirma como esencialmente propio un valor: que la diversidad y la discrepancia son, a su vez, valores que enriquecen al individuo y a la polis en la que vive ${ }^{2}$. A partir de un análisis poco profundo de la Reforma protestante y de los movimientos puritanos que en ella germinaron, algunos han pretendido que se debe a la Reforma y más precisamente al puritanis mo, la introducción del pluralismo en la sociedad, sobre todo por lo que se refiere a la relación entre los poderes públicos y las confesiones religiosas ${ }^{3}$.

Es cierto que la Reforma pluraliza las Iglesias e independiza entre sí las comunidades reformadas, pero no cabe identificar o asemejar rotura y fragmentación con pluralismo, puesto que en realidad lo que resultó fue una multiplicidad de Iglesias o comunidades cerradas en sí mismas o en los estrictos límites de una región o de una nación. Y, por otra parte, si bien es 
verdad que los puritanos defendieron la libertad de conciencia y de opinión, no es menos cierto que no lo hicieron de forma generalizada, sino que en realidad únicamente reivindicaban la libertad de la propia conciencia y de su propia opinión, para convertirse en intolerantes radicales respecto a las opiniones y credos religiosos de los demás: desafiar a la autoridad constituida en nombre de la libertad de conciencia no es pluralismo si lo que reivindicamos para nosotros mismos se lo negamos a los demás. Para la mayor parte de los puritanos, democracia y libertad eran palabras y realidades totalmente despreciables ${ }^{4}$.

\subsection{Aproximación AL CONCEPTO DE PLURALISMO}

En este estudio, entenderé por pluralismo el conjunto de circunstancias sociales y actitudes personales que conforman y delimitan ámbitos de convivencia en que el poder, sea político, económico, cultural, ideológico, etc., está justa y equitativamente distribuido, compartido y reconocido ${ }^{5}$. Esto significa que en una sociedad pluralista, la libertad personal de los individuos que la componen jamás podrá ser invocada como límite de la de los demás, según la asumida y manida máxima de que "mi libertad termina donde comienza la de los demás"; antes al contrario, habrá que afirmar, a partir de una relación de dialecticidad positiva entre los miembros de cualquier sociedad, que la libertad de cada uno de ellos se acrece y consolida en la medida, y solo en la medida, en que se expande y fortalece la libertad de los demás ${ }^{6}$. Nos hallamos, pues, ante una estructura o dinámica dialéctica en la que los elementos que integran la relación entre los polos o extremos dialécticos se implican mutuamente, de manera que no puede existir el uno sin el otro, pues ambas existencias se necesitan; consecuentemente, la sustantivación de cualquiera de esos elementos supone la adjetivación del otro y en el caso límite del procedimiento a su negación, consiguiendo paradójicamente, en este caso, la anulación del polo o extremo que pretendiese suprimir al otro ${ }^{7}$. Precisamente, en razón de esta misma dialecticidad, la afirmación unilateral y exclusiva de alguno de los extremos mencionados, ideología, religión, concepciones sociales o científicas, etc., tendría como consecuencia no solo la negación del no afirmado, sino la aniquilación misma de todo lo que se afirme unilateralmente. Pluralidad equivale, pues, a no exclusividad ${ }^{8}$.

Por otra parte, debe tenerse siempre presente que definir o describir una sociedad como pluralista no equivale a calificarla de multicultural, y viceversa. Acertadamente ha mostrado Sartori que no solo es erróneo asumir esta equivalencia, sino que ambos calificativos pueden llegar a ser intrínsecamente contradictorios en cuanto que el pluralismo es propiedad e indicio de las sociedades abiertas y el multiculturalismo, por el contrario, es atributo de las sociedades cerradas, inflexibles, fijas, estratificadas. Solamente cabría cohonestar pluralismo y multiculturalismo en el supuesto de que este último se asumiera como mera constatación de una situación de hecho, expresión de la existencia de diversas culturas en un mismo espacio geográfico. Considerado así, el multiculturalismo es una concreción histórica, determinada en un 
tiempo y lugar específicos, del pluralismo ${ }^{9}$. Por el contrario, pluralismo y multiculturalismo entran necesariamente en conflicto cuando el segundo se eleva a la categoría de valor o principio de ordenación y configuración de la sociedad, pues así como el multiculturalismo-valor se articula sobre la dispersión y aislamiento cultural, el pluralismo, partiendo siempre de la alteridad y la diversidad, tiende a la apertura relacional y a la convergencia de y entre las culturas existentes en la sociedad: "por definición, el pluralismo implica distinción y separación, pero no abandono pasivo a la heterogeneidad $y$ renuncia a cualquier tendencia relacionalmente convergente entre culturas"10.

Preguntarse por la naturaleza, el significado o los contenidos del pluralismo equivale a acercarse a una cuestión que afecta a todas las dimensiones del hombre y de la sociedad ${ }^{11}$. Con mucha frecuencia, mediante esta palabra solo se significa o constata que la realidad en que vivimos es múltiple, es decir, que se compone de individuos de toda especie: desde el mineral más elemental hasta el hombre. El pluralismo, en esta perspectiva, no va más allá de ser la simple constatación fundamental, aunque social y jurídicamente aséptica, de una realidad que en principio, por su evidencia y simplicidad, no debiera presentar ningún problema especial, al tratarse de un factum connatural a toda sociedad libre. La evidencia del hecho, sin embargo, puede verse trastornada por la confusa obstinación de confundir hechos, deseos e ideas y, en razón de una determinada ideología, buscar la domesticación del hecho a la idea. Precisamente por ello, los problemas asoman cuando del mundo de las meras constataciones y de la simple observación, en su sentido más objetivo, material y concreto, se avanza al ámbito antropológico, social, jurídico o religioso, para preguntarse por el pluralismo como medio de integrar la unidad de lo que en una determinada sociedad se consideran valores humanos fundamentales en la diversidad o dispersión generadas por el ejercicio, ya individual o colectivo, de las libertades personales que, a su vez, son integrantes básicos y necesarios del patrimonio ético y jurídico constitutivo de su identidad personal y social.

En la persona humana, desde la más profunda polaridad de su ser cuerpo-alma (materia-espíritu), varón-mujer (masculinidad-feminidad), persona-sociedad (individuo-comunidad), se verifica, quizás como en ningún otro ser, la dialéctica entre el uno-universal-único y el particular-pluralmúltiple, dado que concreta, en grado máximo, a causa de su dualidad constitutiva, la singularidad y el particularismo, al tiempo que necesariamente ha de realizarlo y realizar-se comunitaria o socialmente:

\footnotetext{
"Cada persona es un todo único y singular. Unidad y unicidad que, hemos de reconocer, es la fuente y origen del profundo deseo que cada ser humano tiene de ser y verse reconocido en su dignidad y singularidad. Es una constante en la experiencia personal que, precisamente, el reconocimiento social es la mejor garantía de estima personal. Sin embargo, no puede olvidarse la paradoja en que se desenvuelve la naturaleza humana al necesitar perentoriamente de otras realidades y de otras personas, es decir de la sociedad, para alcanzar y satisfacer sus fines personales. Esta dimensión social de la naturaleza humana se traduce y concreta en la existencia de una verdadera y auténtica comunidad humana; y si se puede hablar de comunidad
} 
es porque en cada uno de sus miembros existe, más allá o además de sus exclusivas características o propiedades personales, un constitutivo común con los demás"12.

En íntima relación con el pluralismo de la sociedad, la ciencia política y la propia sociología han entendido por pluralismo tanto la doctrina política opuesta a la teoría monista y uniforme del Estado, cuanto el método de análisis y comprensión de las sociedades e instituciones humanas distintas del Estado. El pluralismo no solo supone la separación de Iglesia y Estado, sino, sobre todo, la autonomía de la sociedad civil respecto a ambos. El pluralismo es igualmente amenazado por un Estado brazo secular de una determinada confesión religiosa o por un Estado que politice $y$, en consecuencia, asfixie a la sociedad. Como recordara Sartori, el pluralismo exige reconocer "a Dios lo que es de Dios, al César lo que es del César y a la sociedad civil lo que no es de Dios ni del César"13. El pluralismo moderno, sobre todo tal y como se ha desarrollado en Inglaterra y América entre los años 1900 y 1930, surgió como consecuencia de la imposibilidad estructural que atenazó al Estado moderno a la hora de dar respuesta a importantes problemas surgidos de modos de organización social, hasta entonces, desconocidos, así como de las nuevas formas de articulación de los Estados $^{14}$. La teoría del Estado soberano, elaborada principalmente por juristas, provocaba graves dificultades y desajustes sociales desde el punto de vista político, sobre todo, en la medida en que, casi siempre, soberanía se confundía con omnipresencia y omnipotencia del Estado. Ya a finales de la primera mitad del siglo pasado, el descrédito del Estado soberano fue el principal objetivo crítico de las teorías y doctrinas pluralistas que, desplazando su interés y punto de mira del Estado a la sociedad y grupos sociales, reivindicaron derechos y protagonismo social para grupos profesionales y asociaciones de toda clase, en oposición al Estado ${ }^{15}$.

Tampoco ha sido ajeno a esta consolidación de la práctica democrática en general y del reconocimiento del protagonismo e importancia del pluralismo social, la progresiva aceptación de la importancia social y jurídica de los derechos del hombre que, en cierto modo, ha despolitizado, en su sentido más estricto, el concepto de democracia para convertirlo en modo o marco en que delinear o tipificar el conjunto de las relaciones humanas en el ámbito de la sociedad, asumiendo como fundamento basilar de las mismas el respeto a la igual dignidad de todos los hombres y a sus ideas, aun cuando no se compartan: este precisamente sería el punto de inflexión en que se entrecruzan tolerancia y pluralismo. De este modo, "el ideal democrático, que en un primer momento aparece como conquista de la libertad política, evoluciona, como consecuencia de una necesaria dinámica interna, hacia la defensa y promoción de cualquier libertad, sobre todo de la de pensamiento: con el ideal democrático, necesariamente debía afirmarse la legitimidad, incluso la necesidad, del pluralismo. Precisamente de esa dimensión pluralista extrae su razón de ser el ideal democrático en cuanto proceso concurrencial y competitivo para hacer llegar al poder una verdad o una ideología: la misma fuerza que legitima y garantiza la lucha entre las ideas ha de impedir cualquier ataque contra las personas" 16 . 


\section{2. ¿SOCIEDAD LAICA O SOCIEDAD PLURAL?}

Constituye un tópico generalmente aceptado calificar a las sociedades democráticas, sobre todo en nuestro ámbito occidental, como sociedades laicas o laicizadas. El adjetivo se funda en el hecho de que no cabe encontrar en ellas ni una uniformidad religiosa, ni el predominio de un sentido religioso socialmente generalizado de la vida. Ahora bien, ipueden nuestras sociedades occidentales ser definidas, sin matización alguna, como laicas, laicistas, o como secularizadas, en el sentido de que Dios hubiese desaparecido absolutamente de su horizonte vital? ¿O no es más acorde con la realidad social y jurídica reconocer que las sociedades libres, desarrolladas y democráticas no son ni ateas, ni creyentes, ni agnósticas, ni científicas o filosóficas, sino plurales? ¿No es, sobre todo, el variado abanico de las opciones y decisiones tomadas por los individuos que la forman las que conforman y determinan la realidad social? En todo caso, y siempre con las debidas cautelas, se podría calificar a nuestras sociedades actuales como seculares, en cuanto secularidad equivaldría a pluralidad, en razón de que la sociedad ha de ser espacio en que se hagan efectivos el respeto, la observancia y promoción armónica de los derechos de la persona: la vigencia y plena realización de los derechos personales han de constituirse en meta del conjunto de la sociedad y, simultáneamente, en garantía de libertad e igualdad entre sus miembros, en cuanto condición necesaria para la realización de la justicia.

Para que una sociedad pueda considerarse pluralista ha de estar integrada en sus miembros por personas que se encuentren en ella libre y voluntariamente, sin que su pertenencia se imponga o impida por ningún motivo de exclusividad: apertura y libertad son las dos condiciones que, sobre cualesquiera otras, caracterizan a una sociedad como pluralista. Pluralismo que no significa simple equivalencia o equipolencia con la variedad o pluralidad de grupos ideológicas, confesiones religiosas o cualquier otro tipo de sociedad menor, pues el pluralismo social no es cuestión numérica, cuantitativa o de simple variedad, sino de carácter cualitativo, interno, de estructura, constitución y funcionamiento de cada sociedad concreta.

Resulta, pues, evidente que, en orden a posibilitar la plena realización personal en igualdad y libertad, la sociedad es el lugar donde cada cual se mueve libremente en el ejercicio de sus capacidades, la expresión de sus opiniones, la crítica recepción de las ajenas y la puesta en práctica de sus ideas y creencias a través de determinados comportamientos. El pluralismo es propiedad y característica esencial de las sociedades en que el individuo, y no la ley o el derecho, se constituye en centro y razón de ser de las mismas ${ }^{17}$. La progresiva importancia que en el mundo actual se atribuye a los derechos del hombre, con la excepcionalidad de los vigentes totalitarismos laicistas o teocráticos, es muestra incontestable de cómo lo que existe de común en las personas prevalece sobre lo singular y particular, dado que la alteridad no es solo ni principalmente característica o propiedad de la naturaleza humana, sino constitutivo esencial de su ser-persona: miembros de una misma 
comunidad, los aspectos particulares y plurales o disgregadores (raza, cultura, ideología, religión, etc.) no pueden eclipsar el fundamento común que nos relaciona radicalmente a unos con otros en la esencialidad personal. Esta unidad fundamental en el hecho de la comunidad personal, enriquecida en y enriquecedora de la diversidad, constituye característica esencial de las sociedades pluralistas y abiertas frente a las cerradas, no plurales.

\section{LA LAICIDAD DEL ESTADO}

Es importante, como paso previo al análisis del sentido de la noción que epigrafía este apartado, preguntarse por el propio significado y sentido práctico del término Estado, sin perder de vista que, al principio, el Templo fue anterior al Estado: "Ni siquiera en la sociedad clásica va a desaparecer esta confusión de poderes político-religiosos, por lo que, tanto en Grecia como en Roma, Religión y Estado forman una unidad difícilmente disociable; no en vano los historiadores vemos en Maquiavelo el primer discurso político, y retrasamos hasta Montesquieu la conversión de la política en un discurso científico"18. Entre las varias acepciones con que se utiliza esta palabra, en esta reflexión entenderemos el Estado como la forma jurídica de la comunidad política. Aunque Comunidad política y Estado sean, de hecho, realidades que se suponen y complementan sociológica y jurídicamente, sin embargo, no son idénticas, pues la primera comprende un campo real y un ámbito significativo más amplios que la segunda. Mientras la Comunidad política sería equivalente a Estado-comunidad, decir Estado equivaldría a invocar al Estado-aparato. Es el Estado-aparato el que, en todo caso, podría ser calificado de laico, no el Estado-comunidad,.

¿Cómo, pues, se debe entender o defender la laicidad del Estado dentro de las sociedades plurales en que se inserta el Estado democrático? Para responder adecuadamente a este interrogante, hemos de asumir un primer e importante condicionante: la significación de la laicidad del Estado, e incluso del propio concepto de Estado, aun cuando operativamente asumamos una determinada definición, nos aparece en continua revisión a causa de la vertiginosa rapidez con que, en las sociedades contemporáneas, se suceden los cambios, tanto de carácter ideológico como estructural. Es una constante la continua redefinición a que se ve sometido el propio concepto de laicidad en consonancia con la novedad de elementos socioculturales que, debido al fenómeno globalizador y migratorio, se integran como constitutivos necesarios de las sociedades contemporáneas.

\subsection{SOBRE EL ORIGEN Y SIGNIFICACIÓN DEL TÉRMINO LAICIDAD}

Fluidez tanto del concepto de laicidad como de su propia vivencia o apreciación que ha podido originar que, en la mayoría de los foros jurídicos y políticos, se pierda de vista que el término laico/laicidad ha tenido en nuestra civilización occidental, única en la que se ha fraguado concepto de tal naturaleza, un origen religioso o más precisamente cristiano. No es sencillo determinar con precisión el origen literario y cultural de este término. Y quizás 
la pereza o el olvido que obnubilan la memoria, al distorsionar la matriz histórica del término laicidad, provocan tanta confusión a la hora de llegar a un acuerdo sobre el contenido de este concepto ${ }^{19}$. Ya en los poemas homéricos, Laós significa prevalentemente la porción más numerosa del pueblo, es decir, la de los súbditos o subordinados. Aplicado a la milicia, suele utilizarse para designar a los soldados y guerreros por oposición a sus jefes y, en relación a la sociedad civil, se utiliza para designar al vulgo, los ciudadanos o miembros del pueblo llano, por oposición a las autoridades o gobernantes. En algunos documentos griegos no cristianos, el adjetivo laïkós se utiliza para designar lo público en su sentido más amplio, en cuanto se refiere a algo que se halla al alcance de cualquiera y, por ello, no reservado a los gobernantes, ni a los funcionarios, ni a los mandos militares.

Significación parecida reflejan ciertos papiros que atribuyen este adjetivo a cosas que por ser laicas significa que están a disposición de cualquier persona perteneciente al vulgo popular, aun cuando se trate de tierras o inmuebles cuya nuda propiedad sea del faraón. En un Decreto de Ptolomeo II Filadelfo, de mediados del s. III a. C., sobre la situación jurídica de los esclavos en Siria y Fenicia, laïkós se usa como sinónimo de indígena, nativo de un país vencido administrado por un vencedor. También se utiliza, en otros contextos, para designar un tipo de impuesto, la laïké sintaxis. De nuevo, la significación de fondo que prevalece en esta palabra es la de público, en el sentido de que afecta a todos o que está al alcance de cualquiera. En otro contexto, Aristéneto, mediocre comediógrafo del s. V d. C., utiliza el sustantivado laïkaí -las públicas- para designar a las prostitutas. Las escasas veces que este término aparece en la literatura judía en lengua griega conserva su significación de vulgar, popular, público. En la literatura cristiana, se encuentra por primera vez, indubitadamente testimoniado, en la carta que a finales del s. I escribió S. Clemente Romano a los Corintios y no vuelve a ser utilizado hasta Clemente de Alejandría (n. 150) y Tertuliano (n. 155), apareciendo ya en dos idiomas: griego (laïkós) y latín (laicus). Así como en Clemente tiene el término laïkós siempre un valor adjetival, en Tertuliano, por el contrario, es siempre asumido como sustantivo y en un preciso sentido técnico. La irrupción y generalización de este término en el ámbito del cristianismo y, como lógica consecuencia, en la cultura occidental ocurre en las últimas décadas del siglo II, conservando desde entonces el significado con que fue acuñado, sobre todo, por Tertuliano y Orígenes ${ }^{20}$.

Acuñación que no es ajena al dualismo inaugurado y urgido, con grandes dificultades, por el Cristianismo en la novedad de su comprensión de la relación entre la fe evangélica y las realidades temporales: "Al oír que nosotros esperamos un reino, sacáis precipitadamente la conclusión de que necesariamente ha de tratarse de un reino en el sentido humano"21. Es obligado recordar e insistir en que la palabra laico deriva del griego $\lambda \alpha$ òs (laós) que significa pueblo y que, por tanto, laico no significaría otra cosa que perteneciente al pueblo o ciudadano. Sin perder de vista esta necesaria relación, tanto histórica como lingüística, cabe recordar aquí lo que ya notábamos en otro lugar ${ }^{22}$ sobre la distinción o clasificación, fundada, 
según ellos, en la propia naturaleza, que los griegos realizaban de los hombres según fueran o no personas libres: "La naturaleza, para conservación de la sociedad humana, ha creado a unos seres para mandar y a otros para obedecer. El ser dotado de razón y de previsión manda por naturaleza como dueño, así como el apto por sus facultades corporales para ejecutar las órdenes de otro obedece como esclavo y así la utilidad del señor y del esclavo se confunden... Hesiodo lo expresa rectamente en este verso: 'Procurad, ante todo, la casa, la mujer y el buey arador', porque para el pobre el buey sustituye al esclavo"23. Distinción o segregación tan asumida e integrada en la vida y cultura griegas que el término eleútheros, libre, significa también "perteneciente al pueblo en cuanto contrapuesto a los esclavos y extranjeros" 24 . Eleútheros, pues, "es quien forma parte de una polis (CiudadEstado), como ciudadano de pleno derecho, precisamente en cuanto distinto/opuesto a los esclavos, miembros-componentes de la comunidad política que carecen de libertad"25. Libertad, democracia y ciudadanía o pertenencia al pueblo se convierten en realidades o propiedades inseparables de la conformación del ideal griego de sociedad:

"El hombre helénico rinde culto a la 'libertad' (eleutheria)... que condujo en el siglo $\mathrm{V}$ a. C. a la democracia, forma de gobierno en la que mejor se preserva ese derecho inalienable de la persona. Pablo, el único apóstol de formación helénica, es un 'apóstol de la libertad', acaso por ello mismo... Libertad y democracia son dos conceptos irrompiblemente eslabonados en la mente griega... En plena guerra los griegos convocan frecuentemente la asamblea, que en aquellos tiempos se llama significativamente agora -algo así como 'parlamento'- porque en ella hay plena 'libertad de palabra', lo que desde el siglo V a. C., con Platón y Eurípides, se conoce como parresía... El mismo Tersites, pese a su condición despreciable y a su voz chirriante, puede hablar en la junta de los reyes y jefes guerreros (Iliada 2, 206-220). Por amor a la libertad y a la democracia se enfrentó Grecia con Asia... no solo en los tiempos épicos, sino... en las guerras médicas del s. $V$ a. C., cuyo resultado prodigioso fue que en Europa perviviera el hombre libre frente al hombre persa, esclavo del gran rey... Ya se ve que el hombre helénico desde los tiempos arcaicos se siente destinado a la vida ciudadana... El destino social del hombre comporta para los griegos, como consecuencia necesaria, la libertad de palabra, la mencionada parresía, uno de los derechos inalienables de la persona humana y nota sobresaliente de la democracia griega" 26 .

\subsection{LAICIDAD Y SECULARIZACIÓN}

El separatismo Iglesia-Estado nacido de la llustración y epígono de la Revolución francesa introdujo en la ciencia jurídica y filosófica una nueva acepción de laico que, desde ese momento, comienza a significar lo opuesto a lo que hasta entonces había sido su único significado. Laico, a partir de este momento, va a equivaler a no perteneciente a la Iglesia con el sentido intensivo de opuesto a toda presencia pública de lo religioso en la sociedad. En los sistemas de civil law el término laico se ha utilizado para subrayar la emancipación del ordenamiento jurídico de la tutela de cualquier confesión religiosa. Significación que también se aparta de su clásico significado original no cristiano de popular o público, poniendo de manifiesto la contradicción de quienes simultáneamente proclaman su pertenencia y fidelidad al pueblo con su defensa de la negación de una de las dimensiones 
más populares del ser humano. De este modo, se entiende por laico a quien plantea su vida y su acción al margen o contra la dimensión o aspectos religiosos de la vida; y por laicidad el principio que impide a las autoridades del Estado toda relación con las Confesiones religiosas y niega la más mínima proyección pública del hecho religioso. Así pues, ser laico significa la rotura del horizonte jurídico que separa y divide a los que desarrollan lo personal y lo social como una prolongación vital de sus concepciones religiosas de quienes, aun sin negar la existencia de lo religioso, reducen de tal modo lo religioso al ámbito de lo privado que no le reconocen ningún tipo de incidencia o influencia en la sociedad, sea desde el punto de vista político, jurídico o cultural.

Social e históricamente, al menos tal y como se plantea desde el siglo XVIII, el concepto de laicidad es inseparable del de secularización. El problema de la secularización es una de las grandes cuestiones, más que ideológicas, religiosas o filosóficas, socio-ambientales, presente, como entorno, caldo de cultivo y telón de fondo, en todos los problemas relacionados con la constitución y fundamentos del Estado contemporáneo, y que, a nuestro entender, todavía no ha recibido una suficiente clarificación doctrinal ni desde la reflexión jurídico-constitucional, ni desde la historia de las instituciones, ni desde la propia teoría y configuración de los derechos humanos y su razón de ser ${ }^{27}$. De significar, en un inicial sentido estrictamente jurídico, la transferencia de un bien de la Iglesia a una instancia o poder no religioso, o bien la reducción al estado laical de una persona consagrada, sacerdote o religioso, la secularización pasó a designar los efectos jurídicoadministrativos derivados de la transferencia al Estado de instituciones, educativas o asistenciales, originariamente confesionales ${ }^{28}$.

Al final de su evolución semántica y conceptual, el término secularización ha acabado designando la desaparición o disolución total de lo religioso en el mundo. En el lenguaje jurídico y político actual, el término secularización no significa solo el repliegue de las Iglesias y la emancipación de importantes sectores de la vida social de la tutela eclesiástica, sino que implica el eclipse o evanescencia, en el ámbito social, de cualquier problemática religiosa. Secularización asume, en este momento, el significado de desacralización. La secularización, pues, entendida como un modo de acercamiento a los problemas en el que prima la mera objetividad y la más estricta racionalidad, representa la última fase del establecimiento de la modernidad, así como su consolidación no solo en la realidad social sino, también, en la reflexión jurídica ${ }^{29}$.

\section{3. LA SECULARIZACIÓN PERSONALIZADA}

Si invocábamos líneas arriba la fluidez y versatilidad del concepto de Estado, también hemos de acudir a tales calificativos cuando nos referimos a la secularización ${ }^{30}$. El actual proceso secularizador tiene muy poco que ver con la secularización herencia del "luminoso" absolutismo ilustrado que se sirvió de esta corriente ideológica para enfrentar el Estado absolutista al poder o protagonismo social no tanto de la religión cuanto de la Iglesia 
Católica. A diferencia de esta secularización de carácter institucional, estatal o corporativa, el proceso secularizador contemporáneo se caracteriza, sobre todo, por la emergencia y protagonismo del sujeto personal, del individuo, que se siente y autodefine en exclusiva referencia a sí mismo y orienta su vida y actividad a dar satisfacción a sus deseos personales, centrado originariamente sobre sus propios intereses. Así, por ejemplo, resulta en un ensayo publicado por Gustavo Zagrebelsky, en el diario La Repubblica de 5 de julio de 2005, en el que criticaba acremente, con motivo del diálogo-discusión mantenido entre Habermas y Ratzinger, al que nos referiremos posteriormente, la actitud de los intelectuales que denomina peyorativamente como ateos clericales y a los que, en la medida que se prestan a experiencias de esta clase, atribuye irónica y hasta irrespetuosamente una santa ingenuità - una diabolica astuzia ${ }^{31}$. La secularización actual está, en gran medida, determinada por la transmutación de los deseos e intereses individuales en indiscutibles derechos personales, abocando a la política a problemas y coyunturas desconocidos hasta ahora y generados por el protagonismo que en el ámbito jurídico exigen las pretensiones e intereses del individuo, pues "muchos de nuestros contemporáneos han retomado una antropología que les conduce a utilizar su libertad para cerrarse a sus semejantes" 32 . Individualización del proceso secularizador que responde perfectamente a la hermenéutica de no pocas epistemologías contemporáneas para las que solo el hecho de la certeza subjetiva se conecta intrínsecamente a la verdad, cuya autenticidad se hace depender únicamente del grado y nivel de identificación del sujeto con aquella parte de la realidad que es captada por el mismo ${ }^{33}$.

La misma diversidad y multiplicidad de credos religiosos y de lejanas civilizaciones, cada vez con mayor incidencia en nuestras sociedades occidentales, así como las cosmovisiones y éticas con ellas conexas, en cuanto someten a crisis no solo las identidades religiosas sino las históricas y sociales, exigen a todas luces una redefinición de la laicidad del Estado. Si algo ha quedado claro en el imaginario de nuestra sociedad, después de más de dos siglos de ilustrada y racionalista secularización, es que ni la religión ha sido desplazada del espacio público de la sociedad, según vieja aspiración del absolutismo dieciochesco, ni la razón ha sido faro y sentido de la vida de personas y sociedades en los siglos posteriores a la Ilustración ${ }^{34}$. Recordemos como indiscutible prueba de este fracaso secularizador la irracionalidad del peligroso retruécano que ha caracterizado la sangrienta historia del siglo XX: difícilmente puede achacarse a la oscuridad del sentimiento religioso la tropelía de las dos grandes guerras y las "pequeñas guerras", con millones de muertos a sus espaldas, que ha generado y atizado la "irracional racionalidad" sobre la que teóricamente se asentaron las modernas sociedades, descendientes directas de los aires ilustrados.

No debemos perder de vista, al hilo de esta reflexión, que la racionalidad invocada como principio y seña de la secularización, así como las notas y propiedades esenciales que la identifican y definen, es herencia inequívoca del Cristianismo y, más en concreto, del Cristianismo occidental, pues en ninguna sociedad de la ortodoxia oriental se ha verificado un fenómeno de 
equivalente naturaleza. El concepto, pues, de laicidad o, según algunos, el supuesto principio de laicidad debiera de ser, siquiera como principio metodológico de cualquier planteamiento sobre este asunto, el propuesto o definido por Ferdinand Buisson como aquel en que "el Estado mantiene una posición de neutralidad de cara a todos los cultos y a todas las religiones y es independiente de toda autoridad religiosa y libre de cualquier concepción teológica" 35 .

\subsection{LA LAICIDAD: ¿PROMOCIÓN O EXCLUSIÓN?}

Desde la llustración hasta nuestros días, la laicidad se ha entendido en un sentido exclusivista o duro, reduciendo lo religioso al ámbito de lo privado sin ningún reconocimiento a su proyección pública y social ${ }^{36}$; o bien se ha presentado desde planteamientos abiertos, razonados y, en la medida de lo posible, integradores. Ahora bien, hemos de reconocer que tal y como actualmente suelen abordarse las cuestiones relacionadas con la laicidad, deudoras y esclavas de tantos prejuicios, es muy difícil encontrar cauces que faciliten la superación de oposiciones y contradicciones que surgen del contraste entre las convicciones cristianas, sobre todo católicas, y las condiciones de la laicidad. Precisamente en y desde el intento de superación del tantas veces frustrado diálogo entre los promotores de la laicidad y quienes optan en sus vidas por el compromiso personal de la fe cristiana, nos resultan reveladoras y muy clarificadoras las sugerentes palabras del Prof. Guy Coq, comentando las iniciativas del cardenal Decourtray de cara al restablecimiento de un encuentro permanente entre cristianismo y laicidad:

\footnotetext{
"Esta actitud se caracteriza en principio por una renuncia: la Iglesia renuncia a imponer a la sociedad la imagen que ella tenga de sí misma. En tiempos pasados en que la Iglesia tenía una fuerte implantación en las instituciones de la sociedad, podía imponer socialmente la imagen que tenía de sí misma... La sociedad secular se me antoja más favorable al descubrimiento y recepción de la buena nueva que una sociedad religiosa que constriña las conciencias. Como Iglesia, nos falta coraje para comprender que el Cristianismo no es un aliado de las religiones que se oponen a la laicidad, sino que es más bien aliado de los hombres que acceden a su libertad" 37.
}

En el primero de los casos la laicidad adquiere formas y contenidos militantes o combativos. Sus principios se presentan como socialmente exclusivos y exclusivistas; tiende, en fin, a imponerse como una fuerza más y prevalente, en cuanto revestida de un imaginado plus democrático, en una especie de neoconfesionalidad laicista. Consecuencia necesaria de esta actitud es la aniquilación de la necesaria dimensión social y pública del derecho de libertad religiosa. "Sono un laico, non un laicista": de este modo tan sencillo se autodefinía el filósofo y jurista italiano Norberto Bobbio. Y por si quedaba alguna duda, remachaba su posición: "Non sono un anticlericale". Propició estas palabras la negativa del ilustre filósofo a adherirse al Manifesto laico hecho público el año 1998 y en el que más de 25.000 firmantes se oponían a la financiación de las escuelas católicas por parte del gobierno italiano. El propio Bobbio explica que una de las razones más poderosas que le impidieron adherirse al mencionado manifiesto fue la actitud que traslucía 
el mencionado documento al defender las propias tesis e ideas con "un lenguaje insolente, de rancio anticlericalismo, carente del mínimo respeto... Lo que me ha desagradado del 'manifesto', explicaba Norberto Bobbio, ha sido el tono batallero que en él se utiliza. Un tono no laico, emotivo y cargado de irracional afectividad, que no utiliza la argumentación sólida y que, en realidad, parece rechazar toda forma de diálogo" 38 . Aunque breve, la cita es más que suficiente a la hora de describir las pautas determinantes del emergente fundamentalismo laicista, en la perspectiva de que solo la laicidad, teñida abiertamente de laicismo ideológico, podría legítimamente reivindicar un espacio público en la sociedad.

Resultan paradigmáticas en este sentido las palabras con que hace algunos meses se expresaba el portugués Saramago refiriéndose a Benedicto $\mathrm{XVI}$, en un coloquio con el filósofo italiano Paolo Flores D'Arcais, que publicaba el 14 de octubre de 2009 "I/ Fatto Quotidiano", en coincidencia con la visita a Roma del novelista luso y en el que la fingida ironía del entrevistado de ningún modo oscurece cierta tópica ignorancia a la hora de determinadas referencias o recursos a la historia ${ }^{39}$ :

\begin{abstract}
"Que Ratzinger tenga el valor de invocar a Dios para reforzar su neomedievalismo universal, a un Dios que jamás ha visto, con el que nunca se ha sentado a tomar un café, demuestra solamente el absoluto cinismo intelectual del personaje... A las insolencias reaccionarias de la Iglesia católica hay que responder con la insolencia de la inteligencia viva, del buen sentido, de la palabra responsable. No podemos permitir que la verdad sea ofendida todos los días por presuntos representantes de Dios en la tierra a los que en realidad solo interesa el poder".
\end{abstract}

Nos hallamos, pues, ante una especie de laicidad ideológica o ideología laicista, laicidad de principio y de principios, laicidad de fundamentos que se caracteriza, sobre todo, por su extremo anticlericalismo, en su específico sentido de antieclesial o anticatólico: no en vano, como con frecuencia acontece en nuestros días, con la misma fuerza y rigor que este laicismo de corte pseudodemocrático aherroja de la vida pública la simbología religiosa cristiana, defiende, por ejemplo, la presencia social y la dimensión pública de simbología religiosa islámica.

Curiosamente, esta comprensión de la laicidad supone la negación de la propia laicidad, al convertirse en fuerza combativa en contra de la presencia pública de la religión e incluso a favor de su total desaparición. La laicidadtalante o laicidad-actitud se convierte en laicidad-ideología uniformadora de la sociedad al erigirse en la única con patente democrática en el conjunto social, todo lo contrario a una laicidad secularizada, racional y razonable; o, dicho de otro modo, lo más opuesto a una laicidad inteligente.

En el segundo de los supuestos, por el contrario, la laicidad se plantea y vive como el respeto y promoción, en una sociedad libre, adulta y democrática, de la mayor pluralidad posible de experiencias u opciones jurídicas, culturales, ideológicas y religiosas ${ }^{40}$. Es decir, la laicidad no se enarbola como principio jurídico o como valor ideológico, sino como forma o método que modele y modere racional y razonablemente, en las sociedades pluralistas, formas de vida en común a través del diálogo, exigido por la igual 
dignidad de todo ser humano, y de una política construida como servicio a la sociedad, no como impositora de determinados paradigmas sociales e ideológicos ${ }^{41}$. Lógicamente quienes opten por el primer tipo entenderán que aquel es el único modo de hacer socialmente efectiva una auténtica laicidad, al margen de los, para ellos, engañosos cantos de sirena con los que, desde planteamientos libres y pluralistas, se busca limitar y perfilar la excesiva influencia del Estado en la sociedad. Aquellos que, desde supuestos distintos, se inclinen por la segunda defenderán que lo contrario es subvertir la propia idea de laicidad y los presupuestos de los que parte y en que se apoya, lo que permitiría incluso afirmar que una sociedad o una política serán más laicas cuanto más animen y favorezcan el progreso de un auténtico pluralismo a través de la promoción de las opciones religiosas e ideológicas que se verifican en su seno: "Sería contradecir la 'idea de laicidad', se la injuriaría si no se reconociera a los católicos el derecho de ser católicos y vivir y actuar como tales. En todo caso se les podrá achacar y acusar de no serlo suficientemente: de no pasar de ser tibios y mediocres testigos de la propia $f e " 42$. En el primero de los supuestos, el Estado-comunidad acaba fagocitado por el Estado-aparato que es, donde debe asentarse la auténtica laicidad. En el segundo, los medios de orientación propagandística y vinculación jurídica, así como la propia coactividad de que dispone el Estado-aparato se ordenarán a la consolidación de un Estado-comunidad auténticamente plural y verdaderamente libre.

\subsection{LAICIDAD, DEMOCRACIA Y LIBERTAD}

La auténtica laicidad no significa ni implica oposición o ignorancia de la fe o de la religiosidad y, en sí misma, no equivale ni a ateísmo, agnosticismo o creencia, pues la laicidad es cualidad y característica tanto de ateos como de agnósticos o de profundos creyentes. La laicidad es, sobre todo y principalmente, una forma mentis, un talante, un modo de ser, una manera de enfrentar y analizar las cuestiones fundamentales de la vida personal y social, más que un concepto o principio jurídico, filosófico o político ${ }^{43}$. La laicidad, en cuanto característica del poder público, debe, en consecuencia, consistir más en una actitud que en un principio jurídico, en sentido estricto, que, por su influencia jerárquica en las normas, acabaría constriñendo el ordenamiento y restringiendo algunas de las manifestaciones más genuinas de los creyentes. Sin embargo, siempre ha de tenerse muy claro que la laicidad, en las sociedades plurales y los regímenes democráticos, ha de situarse más en el ámbito de las cualidades personales que en el de las características sociales: se trata de la capacidad de distinguir, teórica y prácticamente, lo que es demostrable racionalmente de aquello que es objeto de la fe, de la creencia, prescindiendo incluso de la mayor, menor o nula adhesión personal que se tenga a una determinada creencia e incluso reconociendo que la adhesión religiosa pueda ser perfectamente razonable, aunque su ámbito fundamental no sea el de la racionalidad.

La laicidad, pues, se mueve en el ámbito del pluralismo que consiste no solo en tolerar sino en la apertura radical a lo que de verdadero hay en lo que 
piensa, dice o vive quien piensa, habla o vive de forma distinta. La laicidad no se identifica con credo, filosofía o ideología alguna, pues, en la medida en que la laicidad fuese deudora o ideal de una determinada ideología o corriente filosófica dejaría de ser laicidad para convertirse más o menos sutil coartada ideológica 44 . Como he puesto de relieve en otras ocasiones, la opción por la laicidad como forma de convivencia plural dentro de los límites de una determinada sociedad consiste, sobre todo, en la actitud personal que capacita y posibilita para articular el propio pensamiento, sea ateo, religioso, materialista o espiritualista, según principios hermenéuticos lógicos que, en su propia coherencia metodológica interna, no pueden estar condicionados por ninguna fe, por ningún sentimiento o interés de la afectividad o de la ideología, pues, en tal caso, siempre se caerá en el "oscurantismo confesional", cualquiera sea su raíz, religiosa o laicista. La laicidad, pues, "consiste en el respeto de la persona humana en su libertad y en la diversidad de su naturaleza en el seno de la creación" 45.

La laicidad, por tanto, o es sinónimo de abierta, receptiva, positiva y dinámica tolerancia o no es nada. En razón del pluralismo en que germina y se nutre la auténtica laicidad, ser laico es estar siempre dispuesto a dudar metódicamente de las propias certezas, raíz indiscutible del pluralismo social, al tiempo que se es capaz de creer radicalmente en determinados valores sabiendo que existen otros que deben ser respetados aun cuando no se esté dispuesto a compartirlos; es poseer la capacidad de distinguir el pensamiento y los sentimientos auténticos de las convicciones fanáticas y de las viscerales reacciones emotivas; es sentirse libre tanto del absoluto de la idolatría como del de la ahistórica e intransigente desacralización, dados el servilismo y coactividad que ambas implican. El auténtico laico tiene siempre presente que el intolerante puede ser cerradamente clerical o facciosamente laicista, ambos, en definitiva y simultáneamente, radical y esencialmente antilaicos. Merece la pena recordar, al respecto, las palabras que escribió hace ya años el siempre maestro de laicidad Norberto Bobbio:

"Las personas sobre las que me he ocupado son dieferentes entre sí por profesión de fe, concepción filosófica, actitud política. De la observación de la irreductibilidad de las últimas creencias he obtenido la lección más grande de mi vida. He aprendido a respetar las ideas ajenas, a pararme ante el secreto de las conciencias, a comprender antes de discutir, a discutir antes que condenar... ya que estoy en ánimo de confesiones, expreso una, quizás superflua: detesto a los fanáticos con toda el alma" 46 .

Como ha recordado recientemente el Tribunal Europeo de Derechos Humanos, la auténtica laicidad valora positivamente la libertad religiosa o, enunciado desde una perspectiva más formalmente jurídica, el derecho de libertad religiosa y su libre ejercicio como "uno de los cimientos de toda sociedad democrática", puesto que "la libertad religiosa, siendo elemento esencial de la identidad de los creyentes y de su concepción de la vida, es también, y sobre todo, un bien preciado para ateos, agnósticos, escépticos e indiferentes, consecuencia necesaria del pluralismo consustancial con una sociedad democrática" 47 . Desde esta perspectiva, cabe concluir que el respeto y protección al plural ejercicio de la libertad religiosa es indicio inequívoco de 
auténtica laicidad y de verdadero pluralismo:

“... el reconocimiento de las libertades más íntimas de la persona exige del Estado de derecho la progresiva integración de la norma jurídica en la esfera de la actividad social directamente relacionada con y derivada de la conciencia del individuo, en su más amplio sentido que, lógicamente, incluye de forma prioritaria y ejemplar la libertad religiosa. El ordenamiento estatal se encuentra abocado a regular determinados aspectos de la actividad social de la persona que derivan o se relacionan, de modo especial, con dimensiones extra o metajurídicas del ser humano. Ante esta exigencia, ¿qué capacidad de respuesta pueden tener sistemas jurídicos que no asumen la conciencia de la persona entre sus principios integradores o informadores? Reconocer relevancia a la conciencia personal y a sus implicaciones sociales, ¿no entraría en contradicción con el garantismo formalista y con la seguridad legal-material, propios de los sistemas jurídicos estatales?"48.

\section{EL TESTIMONIO DE LA FILOSOFÍA: LAICIDAD VS. RELIGIÓN EN RESPETO Y LIBERTAD}

El 19 de enero de 2004 la Katholische Akademie in Bayern organizó en Munich un interesante diálogo entre Jürgen Habermas y el cardenal Joseph Ratzinger. El diálogo se tituló Los fundamentos morales prepolíticos del estado liberal. Cuatro años después, con motivo de la famosa y polémica lección magistral pronunciada por el papa Benedicto XVI en el Aula Magna de la Universidad de Ratisbona, el día 12 de septiembre de 2006, otro filósofo no creyente y convencido materialista también mantuvo un sustancioso diálogo, esta vez por escrito, con las ideas del antiguo cardenal Ratzinger, ya Benedicto XVI. Me refiero a la aportación que bajo el título iDios salve la razón! realiza Gustavo Bueno Martínez al volumen colectivo Dios salve la razón, coordinado por Javier Prades y publicado en Madrid por Ediciones Encuentro el pasado 2008.

\subsection{DEMOCRACIA, LAICIDAD Y RELIGIÓN SEgÚN J. HABERMAS}

Habermas abordó, en su diálogo con el cardenal, el tema de la relación entre religión y Estado liberal-democrático. Para el filósofo alemán la auténtica responsabilidad de la sociedad postsecular no es otra que la de "comprender la secularización cultural y social como un proceso de doble aprendizaje, que obliga tanto a la tradición del lluminismo cuanto a la de la doctrina religiosa a reflexionar sobre sus propios límites" 49 . Y de este modo quedan delimitados los parámetros en que ha de plantearse la laicidad del Estado: que en el momento en que el Estado asumiera como función específica de sus competencias la fijación de los límites y las posibilidades de desarrollo e influencia de lo religioso en la sociedad plural, estaría simultáneamente excluyendo de la sociedad una dimensión necesaria y fundamental para muchos de sus ciudadanos $y$, derivadamente, la propia pluralidad de la sociedad.

La razón secular que se sustrae a la escucha de las razones religiosas, se arriesga a verse privada no solo de un potencial de sentido, sino incluso de todo un sistema de conceptos que la teología, sobre todo en el caso de las confesiones cristianas, ha formulado y desarrollado para pensar, comprender 
y decir el ser, así como para explicar la propia existencia humana, y del que, por otra parte, la filosofía se ha servido abundantemente a lo largo de su historia. Habermas Ilama la atención sobre el hecho de que el fenómeno de la persistencia de la religión en sociedades secularizadas no debe ser considerado como si de un mero dato sociológico se tratara, sin mayor trascendencia. Al contrario, filosofía, sociología, derecho y política, aun cuando se presenten como radicalmente secularizados, deben tomarse muy en serio el fenómeno de pervivencia social de lo religioso como un verdadero desafío cognitivo y como un respetuoso reto social y político ${ }^{50}$.

Sugiere Habermas que la misma dinámica histórica y evolución conceptual de la teología y de la propia religión pueden servir de pauta hermenéutica a la actitud que el Estado ha de mantener respecto a la religión: en relación con la religión la sociedad postsecular debe realizar una tarea semejante a la que la religión llevó adelante con la conciencia mítica, es decir debe enfrentarse al lance de intentar "una secularización no destructiva"; o lo que es lo mismo, ha de llevar a cabo un trabajo de "traducción-adaptación" que, respetando la riqueza conceptual y los recursos éticos y morales contenidos en el lenguaje religioso, los proyecte al ámbito de la sociedad plural, al otro lado de las fronteras en que, en el proceso secularizador, ha quedado recluida la teología. En este sentido, cabe recordar, por ejemplo, como, aunque la modernidad se oponía, en principio, a cualquier pretensión social y pública de la tradición cristiana, sin embargo, en la práctica académica y social, la seguía aceptando como pedagogo sustituto del ideal ejercicio autónomo de la razón, como es patente en filósofos como Kant, Lessing o Hegel.

Con relación a la tesis de Ernst-Wolfgang Böckenförde, según el cual "el Estado secularizado vive de presupuestos que no es capaz de garantizar" 51 , Habermas defiende que el Estado liberal no tiene, per se, necesidad de recurrir a tradiciones distintas de la propia, por ejemplo de tipo religioso, para generar en la conciencia de los ciudadanos el vínculo mínimo de solidaridad necesario en todo Estado en orden a evitar cualquier brote de individualismo destructivo. Pero esto no equivale a que el Estado secularizado no deba considerar positivamente el patrimonio de las tradiciones religiosas. Al contrario, reafirma Habermas, la actitud de la filosofía en relación con las tradiciones religiosas debe ser no solo de respeto, sino de auténtica disposición de aprender ${ }^{52}$. Tarea urgente de las tradiciones religiosas es la renuncia al dogmatismo y a la coerción de las conciencias, para, de este modo, convertirse en depositarias y transmisoras de valores e ideas que, de otro modo, acabarían perdiéndose; y de forma especial, de la capacidad de percibir, sentir, expresar y razonar la vida truncada, los fracasos existenciales o las patologías sociales, ofreciendo, a su vez, pautas de integración personal y social de estas situaciones límite.

Es casi un axioma de la vida social y cultura actuales que, a diferencia de la casi ausencia de proposiciones éticas en el pensamiento postmetafísico, como consecuencia de la renuncia a todo concepto o modelo de vida buena y ejemplar que connote, de modo genérico, vinculaciones u obligaciones, en la 
vida característica de las confesiones se conserva una realidad o dimensión intactas, algo que solo en la religión se da: la posibilidad de percibir y de expresar, en forma clara, objetivada por relación a la trascendencia y absolutamente diferenciada, la vida deshonesta, las patologías sociales, los fallos en los proyectos de vida personales e individuales y la deformación de los contextos vitales degradados 53 .

Insiste Habermas en el patrimonio de conceptos que conservan y trasmiten las tradiciones religiosas, así como en el deber de la filosofía de llevar adelante el compromiso de 'traducción' que desde Hegel a Benjamin la ha hecho grande, para concluir que el respeto del Estado por la religión, en paridad con la abstención de juicio sobre las creencias u opciones religiosas de sus ciudadanos, auténtico quicio de la laicidad, se funda en la consideración de la diversidad de las personas y en la atención a la diferenciación de los modos de vida que afectan a la integridad y autenticidad, en primer lugar, de las convicciones religiosas. Ahora bien, el respeto solo es el principio, pues la filosofía y como ella tanto la teoría del Estado como el ejercicio de funciones y competencias del propio Estado tienen razón y motivos para relacionarse con las tradiciones religiosas en una actitud de disponibilidad para aprender 54 .

De este modo, el proceso de secularización acaba convirtiéndose en un proceso de "aprendizaje complementario". Solo en un Estado de derecho no democrático se podría responder negativamente a la pregunta de Böckenförde: “¿hasta qué extremo los pueblos que forman un Estado pueden vivir únicamente de la garantía de la libertad individual sin un vínculo o lazo que les una y que preceda y anteceda a esta libertad?"55. Ahora bien, el Estado de derecho constituido en forma democrática es aquel que, por una parte, garantiza la libertad negativa de aquellos miembros de la sociedad que principalmente se preocupan de su bien particular; pero que, sobre todo, promociona las denominadas libertades comunicativas, transversales, mediante las que impulsa la participación de sus ciudadanos en la discusión pública de aquellos temas y cuestiones que afectan a todos ${ }^{56}$.

El coloquio que ha dado razón a este apartado se cerró con una manifestación de ambos oradores para reclamar una actitud de diálogo sincero y abierto como mutuo aprendizaje y común purificación que comprometa tanto a la filosofía y a la política, que optan por la acción y la reflexión etsi Deus non daretur, como a la teología que en su reflexión sobre la sociedad y la persona humana parte del quia Deus datur. Y todo ello, sin olvidar ni perder de vista que en la actualidad los dos componentes fundamentales de la cultura occidental, la razón secular y la razón creyente, no pueden pretender la exclusividad, ni teórica ni práctica, en el mundo contemporáneo, debido a la variedad de ideologías y opciones religiosas presentes en las sociedades pluralistas actuales. De hecho, ni la religión cristiana, ni la secularizada racionalidad occidental son realidades universales $y$, en consecuencia, todos, creyentes, ateos o agnósticos, han de asumir el supuesto de que no existe una fórmula, racional, ética o religiosa, que opere de punto de unión concreto de todos los hombres. 
4.2. El Cristianismo, garante de racionalidad y laicidad en el PENSAMIENTO DE GUSTAVO BUENO

Aun cuando la exposición del profesor Bueno no se refiere directa y principalmente al problema de la laicidad, sin embargo, de su planteamiento pueden extraerse elementos suficientes para dar razón del tipo de laicidad que puede tener sentido y valor en toda sociedad en que prevalezca el principio de la razón humana sobre cualquier otro principio o postulado ideológico, según se desprende de las propias palabras del filósofo cuando se refiere a una de las posibles concreciones del por nuestro autor denominado delirio gnóstico, indiscutible caldo de cultivo de políticos e intelectuales( $¿$ ?) españoles:

"Los peligros de una educación popular masiva desde supuestos estrictamente laicos... son cada vez mayores... Los gobiernos que encuentran en el laicismo el cauce infalible para una educación racional ignoran, por completo, desde su panfilismo humanista, el estado de la cuestión, que afecta no solamente a los grupos analfabetos de nuestra sociedad, sino también a los grupos semicultos y aun a los que están provistos de una formación tecnológica especializada, incluso científica" 57.

La lente o perspectiva de análisis que asume el profesor Bueno en su discurso es, como se desprende del propio título, la razón y, en consecuencia, la racionalidad como propiedad esencial, y no solo como característica, de análisis y de conformación de la sociedad; y la finalidad que se propone es traducir la lección pronunciada por Benedicto XVI "a las coordenadas del materialismo filosófico" que profesa. El interés que este acercamiento nos suscita deriva, sobre todo, de la circunstancia de que, en este ensayo, se opera continuamente con dos categorías esenciales en la configuración de la laicidad: la racionalidad y la apertura al análisis y la confrontación de cualquier idea o actitud, manteniendo siempre el principio-valor de la libertad.

Ya desde el inicio de su ensayo, al precisar el sentido y significado del término razón, en su esencial y necesaria dimensión de racionalidad operatoria u operante, precisa Bueno que, dado que la racionalidad de una persona se precisa y determina en el proceso de interacción con otras personas, pero no en la autista contemplación de su solitaria e individual identidad, por muy sublime que esta sea, cabe concluir que ni al inmóvil Dios aristotélico, ni a la monoteísta-unitaria divinidad de judíos y musulmanes, se les puede aplicar el atributo de la racionalidad. Situación completamente distinta en el caso del Dios trinitario del catolicismo, en que una persona divina está en relación con las otras dos:

“... si una persona es racional lo será en el proceso de interacción con otras personas, pero no en su sublime "soledad autista"; por tanto, el Dios de Aristóteles no puede recibir tampoco por esta vía el predicado de racional, porque el Dios de Aristóteles no puede hablar consigo mismo ni con el Mundo, al que no ha creado y al que desconoce. En consecuencia, cuando se aplica el logos a alguna persona divina es porque está en relación con otras personas divinas; situación que las religiones monoteístasunitaristas, tales como el judaísmo o el islamismo, no pueden contemplar, y sí en cambio la religión católica, por su dogma del Dios trinitario de la Revelación que estudia la Teología dogmática (y que no cabe confundir con la Teología natural)" ${ }^{58 .}$ 
También deja claro Bueno qué significación tiene, en su razonamiento, el concepto Dios. Más allá del Dios de Aristóteles o del Dios de la teología natural, cuyas conceptualizaciones, según él, han sido determinantes de la idea de Dios en los monoteísmos judío y musulmán, asume en su discurso al Dios cristiano, trino e historificado a través de la unión hipostática de la segunda de sus personas ${ }^{59}$. A partir de aquí, Gustavo Bueno aborda, en los siguientes términos, el reto de uno de los interrogantes esenciales de su diálogo con Benedicto XVI, que no es otra cosa que la pregunta fundamental sobre la relación de Dios con la razón:

"Muy difícil es determinar qué tenga que ver Dios con la Razón, ante todo cuando nos referimos a la llamada Teología voluntarista, de larga tradición (Avicebrón, Algacel, Pedro Damián, Escoto, Descartes, Calvino, Pascal, Schopenhauer, Unamuno)... Pero también es muy difícil determinar qué tenga que ver Dios con la Razón cuando nos referimos al Dios de la llamada Teología intelectualista, la de Aristóteles (que concibe a Dios como un "Pensamiento del Pensamiento") o la de santo Tomás de Aquino (que concibe a Dios como el Ipsum intelligere subsistens)... Pero mucho tiene que ver Dios con la Razón cuando nos referimos al Dios cristiano, al Verbo Divino que se hace Hombre en la Persona de Cristo, para salvar al Género humano de la degeneración y aun de la destrucción derivada de su pecado original (cualquiera que sea el concepto que de este pecado se mantenga)... La cuestión estriba, por tanto, suponemos, en reconocer que, desde el punto de vista de la Teología dogmática del cristianismo tradicional, Dios salvador ha de tener, entre sus misiones especiales, la misión de "salvar a la razón". La cuestión estriba en la dificultad de reconocer, desde el materialismo filosófico, la posibilidad misma de una racionalidad que haya de ser salvada de una supuesta degeneración original y constante, la posibilidad de dar algún sentido... a la supuesta necesidad de algún tipo de ayuda externa que sea capaz... de salvarla de su destrucción total... Solo si, desde posiciones no teológicas, sino materialistas, podemos reconocer algún sentido al proceso de "degeneración de la razón", podremos entender, incluso atender -es decir, tomar en serio, "dar beligerancia"-, a la fórmula teológica que reconoce a Dios como un principio de salvación de la razón humana degenerada" 60 .

Ahora bien, ¿en qué sentido y con qué nivel de autenticidad se puede pretender que la razón necesite ser salvada? De nuevo, el filósofo formaliza con total precisión el ámbito y límites de la proposición del problema:

"Pero no es de la racionalidad trastornada o degenerada a escala individual de lo que nos importa hablar aquí (en el momento de referirnos a los efectos salvíficos que específicamente pudieran atribuirse a la religión cristiana), ni tampoco de los efectos salvíficos que puedan ir asociados a determinados "remedios religiosos", en general, sin excluir a priori los exorcismos... A lo que nos referimos es a la posibilidad de reconocer procesos de "degeneración de la razón" que puedan ser definidos a escala histórica (social, por tanto), y en función de los cuales la acción soteriológica de la religión (o del Dios revelado que actúa por su mediación) pueda ya atribuirse precisamente y específicamente al cristianismo, más que a las otras religiones del libro, o a cualquier otra religión, incluidas las secundarias... los trastornos de la razón que cabe delimitar en determinadas épocas históricas, es decir, las desviaciones, si puede llamarse así, de una racionalidad que ya hubiera cristalizado en alguna tradición institucional, permite y requiere un análisis llevado a cabo mediante conceptos idiográficos 0 , al menos, específicos. Y esto significa que, si en el curso de estas desviaciones de la racionalidad, delimitadas a escala histórica, puede reconocerse la acción soteriológica de una religión precisa que, como la cristiana, apela a Dios como norma de la salvación, ya podremos conceder que encierran algún sentido las palabras de quienes ruegan a Dios que "salve a la Razón"... en los términos históricos del 
analista que se refiere a desviaciones o trastornos específicos de una racionalidad ya especificada y definida en términos positivos, dentro de coordenadas culturales y sociales precisas y susceptibles de recibir la influencia correctora de instituciones también precisas y, entre ellas, la influencia de esa "institución divina" característica que es la Iglesia católica. Suponiendo "ya en marcha", in medias res, a partir de una determinada época histórica, instituciones cuya racionalidad pueda considerarse ya refinada y evolucionada, dentro de sus coordenadas históricas -como puedan serlo determinadas instituciones tecnológicas (arquitectura, música, ingeniería), políticas, militares, comerciales o científicas-, podremos también hablar, y hablamos de hecho, de desviaciones -metafóricamente, de enfermedades y trastornos- de la racionalidad de estas instituciones" 61 .

Entiende el profesor Bueno, en el ensayo que nos ocupa, que estas desviaciones de la racionalidad en el ámbito general de la sociedad, más allá de las pública y políticamente irrelevantes desviaciones o malformaciones de las racionalidades individuales, pueden verificarse, entre otros, en cuatro supuestos fundamentales:

a) Ia desviación supersticiosa, "en el sentido amplio que incluye por ejemplo a la magia negra o a la magia blanca -"teúrgia"-, a los fetiches, a los talismanes, amuletos, conjuros, encantamientos, hechicerías, sortilegios, horóscopos, adivinaciones... que renacen con inusitado vigor en las sociedades industriales de nuestros días"62;

b) Ia de origen mitológico, también denominada por Bueno como ideología delirante, "que, sin perjuicio de sus componentes racionales, conducen a figuras que podrían llamarse monstruosas o irracionales, por relación a otros cánones de racionalidad que hayan sido institucionalizados como tales, por ejemplo, el canon de la causalidad material, el canon de la demostración geométrica, etc. ... pero no por ser monstruosos... dejarán de ser "productos de la razón”... productos enfermos, si se prefiere; a la manera como los tumores malignos de un organismo son también productos vivientes segregados por este organismo cuyo desarrollo se mantiene dentro de la norma de su especie"63;

c) la nihilista concretada, según nuestro autor, "en versiones suyas tales como el relativismo, la trivialización o el "posmodernismo". Si estas desviaciones pueden considerarse como trastornos de la racionalidad es porque afectan, en principio, a la racionalidad misma, y en consecuencia determinan una "crisis de confianza" en las expectativas de las instituciones consideradas racionales" 64 ;

d) así como, finalmente, la institucional o dogmático-fundamentalista, contrastada en "aquellas situaciones en las cuales determinadas corrientes de racionalidad no pueden mantener una coexistencia recurrente con otras corrientes instituidas de su mismo género, y se declaran incompatibles con ellas, tendiendo por tanto a reducirlas, a neutralizarlas, o incluso a destruirlas" 65.

Según Bueno, desde sus comienzos, el cristianismo hubo de enfrentarse a las abundantes supersticiones extendidas a lo largo del imperio romano, 
procedentes unas de desviaciones de la propia religión romana y originarias otras de las partes orientales del mismo imperio, racionalizándolas, neutralizándolas y desactivándolas, a la vez que establecía un canon de racionalidad, precisamente a través de su referencia a un Dios "omnisciente, omnipotente y bondadoso, capaz de hablar a los hombres corrientes, como pecadores o artesanos"66. Otro tanto cabe decir de la oposición, tanto filosófica como teológica, de los teólogos cristianos (desde San Ireneo a Lactancio, pasando por San Hipólito) al extravío de la razón generado por la influencia, en el ámbito del helenismo, del delirio gnóstico, de tanta actualidad y chabacana popularidad en muchos de sus apéndices más irracionales: "la teología católica, precisamente en su proyecto de exploración de los dogmas revelados por el Verbo divino mediante "la razón"... logró transformar muchas de las ideas griegas en otras ideas que fueron precursoras de algunas de las ideas modernas más señaladas, pongamos por caso, la Idea de la Sustancia material con locación no circunscriptiva, es decir, incorpórea, implicada en la teoría de la transustanciación eucarística, y precursora de principios de la teoría electromagnética o de la física cuántica"67. Y ante el escepticismo universal, el nihilismo, relativismo y subjetivismo psicologista, síntoma de inequívocas patologías de la razón y fundamento doctrinal e ideológico de los defensores de los postulados más extremos de laicidad, Bueno apunta que "cabría ver también la fe en Dios omnisciente y humano de la Teología cristiana como una medicina que ha salvado y aún puede seguir salvando a muchos grupos de personas de esa dolencia extrema de la razón, que no puede ser derivada de factores exógenos" 68.

Por último, y en contra del tópico tan extendido en algunos ambientes de una intelectualidad más preocupada por responder a serviles intereses políticos o ideológicos que por buscar la justicia desde los parámetros de la razón, el filósofo materialista insiste en que, frente al despotismo fundamentalista del imperio romano, el cristianismo primitivo "pudo ir creando un amplio recinto de libertad frente al despotismo totalitario de la 'Ciudad Terrena'” 69. Ámbito de libertad, antitotalitario y antifundamentalista, que, a pesar de la defección que pudieron suponer algunas actitudes de la Iglesia desde que Teodosio declarase al Cristianismo religión oficial del imperio, fue doctrinal y teóricamente fundamentado y asentado por Sto. Tomás de Aquino, en el siglo XIII, "al establecer las relaciones entre la Razón natural y la Revelación sobrenatural, reconociendo la imposibilidad de imponer esta Revelación por la fuerza. Asimismo habría sido el cristianismo quien propició el modo general de relación de los Estados con la Iglesia, a través de la doctrina de las "dos sociedades perfectas", cada una en su género, frente al Ilamado "agustinismo político", pero también frente a la teocracia arriana o islámica"70. Es precisamente, según Bueno, la dimensión trinitaria del Dios cristiano la que propicia su radical oposición a la irracionalidad de los dogmatismos fundamentalistas, cualquiera sea el disfraz con que se ofrezcan, incluido el democrático:

"El Dios trino del cristianismo tiene una estructura similar a la de las personas humanas que han desarrollado formas de racionalidad más potentes a través de sus 
instituciones históricas; de una racionalidad que no es solitaria ni autista, como lo es el Dios de Aristóteles o el de Mahoma; de un Dios que también es creador de un Mundo, que no es caprichoso o aleatorio, sino sometido a reglas que han sido contrastadas en el "Consejo divino", y solo ante las cuales las grandes masas populares pueden mantenerse dentro de unos límites capaces de defenderse del pánico, del delirio, de la superstición o del horror. Un Dios que sin embargo mantiene las distancias respecto del mundo, y por ello puede alterarlo o modificarlo, a través de la tecnología y de la ciencia; un Dios en el que se reconoce una razón política, una razón física, una razón tecnológica, muy próxima a las formas de racionalidad que históricamente se han desarrollado en los pueblos Ilamados "civilizados". No es difícil comprender, por tanto, que es precisamente el Dios de los cristianos quien ha salvado a la Razón humana a lo largo de la historia de Occidente, y hasta qué punto tiene sentido afirmar que podrá seguir salvándola en los momentos impredecibles, pero inexcusables, en los cuales los contactos de las "sociedades occidentales" con las "sociedades orientales", o de cualquier otra estirpe, ponga a la racionalidad históricamente conquistada ante el peligro de sus mayores extravíos" 71.

\section{5. ¿PERPLEJIDAD O CONJETURA DE FUTURO?}

Aunque en esta exposición no hayamos pretendido agotar, ni siquiera plantear extensamente, la relación que a lo largo, sobre todo, de los tres últimos siglos, ha entrelazado secularización con laicidad y valores sociales e ideológicos con sistemas políticos: cabe, sin embargo, constatar que en la medida en que se opte por un sistema jurídico e ideológico auténticamente democrático y respetuoso con los derechos del hombre, la laicidad derivada de una verdadera secularización no implica jamás la negación o minusvaloración de la dimensión religiosa de personas o sociedades, sino que debe consistir en la gestión política, con sus necesarias e intrínsecas consecuencias e implicaciones jurídicas, de lo religioso y no en la gestión religiosa de lo político ${ }^{72}$. Y ello sin perder de vista que la secularización es uno de los paradigmas de mayor ambivalencia en sociología e historia de la religión, indispensable, por una parte, y continuamente sometido a crítica, por otra $^{73}$. Desde esta perspectiva, me atrevo a sugerir un nuevo calificativo o denominación del polisémico laicidad que, pienso, se aviene mejor con el modelo de Estado plural y democrático. Estimo más acorde con los marcos constitucionales de las auténticas democracias y con los principios que los delimitan hablar de laicidad abierta o racional como característica de los Estados que se conforman en y a partir de comunidades políticas resultado de verdaderas sociedades abiertas.

La laicidad abierta, racional o inteligente, en feliz expresión esta última de R. Debray, más allá de la reducida problemática en torno a las viejas y manidas cuestiones en que todavía siguen anclados algunos teóricos de la laicidad, tales como la escuela, la financiación del ejercicio de las creencias religiosas o la trascendencia pública de la simbología religiosa, tiende primaria y fundamentalmente a situar cualquier asunto relacionado con las confesiones religiosas en el horizonte de la libertad, sobre todo, en el ámbito del ejercicio público de la misma, en cuanto concreción del derecho en que toda libertad se verifica jurídicamente. Se trata de una laicidad que se presenta y define como positiva expresión de racionalidad y razonabilidad, 
como muestra o afirmación de solidaridad, de igualdad, de valores democráticos y de cualesquiera otros propios y específicos del ser humano, que provocan y sustentan un diálogo permanente con todas las demás opciones y concepciones filosóficas, teológicas o ideológicas:

"El otrora seguidor del Che Guevara ha entrado en la reflexión sobre la religión en la sociedad con propuestas sensatas y análisis dignos de tener en cuenta. No nos vendrá mal mirar allende los Pirineos. R. Debray contrapone la laicidad inteligente a la laicidad incompetente típica de la demandada neutralidad del Estado en cuestiones de religión y sentido último. Esta neutralidad, que fue, sin duda, un avance en la superación de los conflictos desatados por las guerras de religión en Europa, se muestra ahora demasiado escuálida... Lo triste del debate de la laicidad es que parece que estamos condenados al 'frentismo' de cada una de estas posturas beligerantes.

"Aquí aparece de nuevo R. Debray apelando a la laicidad inteligente: la de un Estado y una Iglesia condenados a entenderse. Porque en políticas sociales, en cuestiones de vida y muerte (nacimiento, eutanasia), de género, de emigración, integración social, multiculturalidad, educación, son inevitables los roces. Hay, se quiera o no, incidencias de la política con el sentido. Y al Estado neutral no le puede ser indiferente -como hoy vemos con el caso del terrorismo islámico o nacionalista- cualquier ideología o religión. La cuestión es sutil, de talante y de actitudes de diálogo y encuentro por ambas partes. Requiere hombres capaces de llevarlas a cabo.

"La laicidad inteligente solicita que el laicista entienda que ya los creyentes no le quieren disputar el poder al Estado. Y, por ello, que no pretenda esgrimir la ideología laicista ni tener el monopolio de la racionalidad y del saber ('científico') ni de las soluciones a cuestiones de moral social. El creyente debe saber que está en una sociedad pluralista, laica, donde no posee el monopolio ni del sentido de la vida ni de la moral ni tampoco de las soluciones adecuadas a los complejos problemas sociales.

"La laicidad inteligente se parece mucho a lo que J. B. Metz, desde Alemania, denomina 'dialéctica de la secularización': Ia creación de una actitud autocrítica frente a las propias limitaciones y perversiones, tanto de la religión como de la laicidad, a fin de hallar caminos de encuentro que ayuden a construir realmente una sociedad democrática, pluralista y tolerante donde los seres humanos puedan ser y vivir mejor. En este punto se pueden y deben encontrar laicistas creyentes y no creyentes" 74 .

La laicidad y la actitud laica del Estado están abocadas, en el entorno de las sociedades auténticamente plurales, a constituir un espacio cierto de comunicación entre credos religiosos y convicciones ideológicas; a propiciar un lugar de protección y garantía para la expresión de las distintas confesiones y de las diferentes ideologías que conforman la sociedad y no a erigir cercos y muros que las reprima y contenga bajo la férula de un Estado disimuladamente tiránico ${ }^{75}$. En este sentido, la laicidad del Estado debiera de ser un verdadero medio y garantía para que las confesiones religiosas no acaben relegadas y constreñidas al estricto ámbito de lo privado. Por el contrario, debiera de propiciar su expresión y manifestación con total libertad, sin exigir privilegios ni convertirse en grupos de presión o lobbies promotores de individualistas y parciales intereses, como, por ejemplo, sucede con determinadas ideologías. Laicidad y pluralidad constituyen, pues, tanto desde una perspectiva jurídica como, incluso, ética, focos sobre los que han de articular sus relaciones no ya el Estado y las confesiones religiosas, sino, sobre todo, el Estado y la sociedad. El Estado, pues, es y debe ser laico; pero la sociedad no es laica, puesto que en ella se verifica la presencia de diferentes cosmovisiones, ideologías, confesiones religiosas y modos y formas 
de espiritualidad y de comprensión antropológica llamadas a enfrentarse a y rechazar cualquier tipo de intolerancia o de violencia tendentes a hacer prevalecer, e incluso imponer, unas determinadas convicciones ideológicas, religiosas o morales ${ }^{76}$.

Así pues, cara a la sociedad plural, al Estado laico le debe repugnar reducir dentro de los límites siempre sofocantes de una determinada ideología la resolución de cuestiones o problemas fundamentales de la vida humana directamente entroncados en la autodeterminación personal. Sin embargo, esto no significa que la laicidad consista en restringir el papel del Estado al de mero y pasivo garante formal de la coexistencia social. Al Estado laico le corresponde, entre sus numerosas funciones, la de garantizar, no generar o crear, una ética pública objetiva y compartida que ha de anclarse en un firme sí a la tutela sin fisuras de los derechos humanos y, correlativamente, en un igualmente firme no a cualquier lesión o disminución del ejercicio efectivo de cualquiera de ellos. El Estado laico, en los sistemas democráticos, no puede considerarse infalible, ni puede pretender la posesión de certezas absolutas. En consecuencia, es justísimo que el Estado democrático esté continuamente dudando de sí mismo y se halle siempre dispuesto a volver sobre sus propios pasos; pero, así como es necesario, en toda democracia, dudar continuamente de nuestro modo de pensar o de comprender el bien, nadie está legitimado, mucho menos el Estado, en razón de los propios principios que dan sentido a la democracia, a dudar de que el bien exista y a renunciar al compromiso de realizarlo. Laicidad y sociedad pluralista adquieren su pleno sentido y razón de ser en la perspectiva de la objetividad axiológica de la posibilidad del bien y la verdad como y en cuanto objetivo necesario para la realización de la justicia77.

Las coordenadas fundamentales que conforman y determinan las sociedades abiertas son la libertad y el pluralismo, una de cuyas características fundamentales es el fomento de la relación e intercambio entre personas y grupos. Sociedades en las que, a su vez, se constata la ausencia de estratificación en su estructura, tanto en lo personal como en lo económico, político o cultural. Ello significa que las relaciones entre los distintos status, ya sean sociales, económicos, culturales o políticos, son de una absoluta fluidez y movilidad. Las sociedades abiertas, pues, constituyen la conformación humana más opuesta a los grupos cerrados, a las castas, a los ghetos y a las diferencias accidentales elevadas a esenciales. La laicidad abierta, racional e inteligente que se corresponde con la laicidad-actitud positiva y pluralista, radicalmente contraria a la laicidad-principio de orden jurídico o ideología estatal, se articula en las sociedades abiertas y auténticamente democráticas, sobre todo y ante todo, como garantía protectora de la sagaz voracidad fagocitadora de los modernos Estados formalmente democráticos en el intento de uniformar las sociedades plurales y pluriideológicas. El Estado, en una sociedad abierta, no tiene por qué ir más allá de ser árbitro y garante de libertad y pluralismo. La exquisita neutralidad que se exige a todo árbitro y moderador es la que debe observar, en todos los órdenes, el Estado en las sociedades abiertas. Así, por ejemplo, lo recuerda, 
en reciente sentencia, el Tribunal Supremo Español cuando afirma que la positiva neutralidad del Estado así como el fomento y respeto del pluralismo son principios que no solo no deben ser sobrepasados en ningún momento por los poderes públicos, sino que deben ser principios informadores y determinantes de la actuación del Estado de derecho:

"La diferenciación que acaba de hacerse marca los límites que tiene la actuación del Estado en materia educativa y, sobre todo, acota el terreno propio en que regirá la proscripción de adoctrinamiento que sobre él pesa por la neutralidad ideológica a que viene obligado... Por el contrario, será exigible una posición de neutralidad por parte del poder público cuando se esté ante valores distintos de los anteriores. Estos otros valores deberán ser expuestos de manera rigurosamente objetiva, con la exclusiva finalidad de instruir o informar sobre el pluralismo realmente existente en la sociedad acerca de determinadas cuestiones que son objeto de polémica... Lo hasta aquí expuesto nos lleva directamente al examen de los problemas restantes, referentes al alcance y límites del derecho a la libertad ideológica y religiosa proclamado en el art. 16.1 CE. Respecto de este derecho debemos decir que está constituido básicamente por la posibilidad reconocida a toda persona de elegir libremente sus concepciones morales o ideológicas y de exteriorizarlas, con la garantía de no poder ser perseguido o sancionado por ellas... La compatibilidad será de apreciar siempre que la exposición de esa diversidad se haga con neutralidad y sin adoctrinamiento. Es decir, dando cuenta de la realidad y del contenido de las diferentes concepciones, sin presiones dirigidas a la captación de voluntades a favor de alguna de ellas... Está referido al mundo de las creencias y de los modelos de conducta individual que, con independencia del deber de respetar esa moral común subyacente en los derechos fundamentales, cada persona es libre de elegir para sí y de transmitir a sus hijos... Sin embargo, dentro del espacio propio de lo que sean planteamientos ideológicos, religiosos y morales individuales, en los que existan diferencias y debates sociales, la enseñanza se debe limitar a exponerlos e informar sobre ellos con neutralidad, sin ningún adoctrinamiento, para, de esta forma, respetar el espacio de libertad consustancial a la convivencia constitucional...

"Ello es consecuencia del pluralismo, consagrado como valor superior de nuestro ordenamiento jurídico, y del deber de neutralidad ideológica del Estado, que prohíbe a este incurrir en cualquier forma de proselitismo. Las materias que el Estado, en su irrenunciable función de programación de la enseñanza, califica como obligatorias no deben ser pretexto para tratar de persuadir a los alumnos sobre ideas y doctrinas que -independientemente de que estén mejor o peor argumentadas- reflejan tomas de posición sobre problemas sobre los que no existe un generalizado consenso moral en la sociedad española. En una sociedad democrática, no debe ser la Administración educativa -ni tampoco los centros docentes, ni los concretos profesores- quien se erija en árbitro de las cuestiones morales controvertidas. Estas pertenecen al ámbito del libre debate en la sociedad civil, donde no se da la relación vertical profesoralumno, y por supuesto al de las conciencias individuales..."78.

Árbitro y moderador, ni portaestandarte ideológico, ni orientador, ni director, ni pedagogo, ni conformador o controlador determinante de criterios o valores sociales, ni vigía o gran hermano orweliano. Solo en los regímenes totalitarios, el Estado acaba invadiendo, totalizando y manipulando los espacios sociales e ideológicos, en orden a provocar mutaciones sociales, vitales e ideológicas, de acuerdo con opciones ideológicas afines al correspondiente aparato estatal y, con frecuencia, extrañas y ajenas a las propias sociedades así manipuladas. Pues, como recordara Arendt: "La preparación para el totalitarismo ha tenido éxito cuando... los hombres pierden la capacidad tanto para la experiencia como para el pensamiento. El 
objeto ideal de la dominación totalitaria no es el nazi convencido o el comunista convencido, sino las personas para quienes ya no existen la distinción entre el hecho y la ficción y la distinción entre lo verdadero y lo falso"79.

\section{BIBLIOGRAFÍA CITADA}

AGAZZI, Evandro (2000): “La verità e 'Ie' verità”, en: MARSONET, Michele (ed.): Il concetto di verità nel pensiero occidentale (Génova, Editorial II Nuovo Melangolo s. r. I.) pp. 9-17.

ARENDT, Hannah (1987): Los orígenes del totalitarismo (Traducc. Guillermo SOLANA, Madrid, Taurus Ediciones, S. A.). 618 pp.

ARISTÓteles (1957): Política (Recognovit et brevique adnotatione critica instruxit Walter David ROSS, Londres, Oxford University Press). 283 pp.

BAUBÉROT, Jean (2001): "La laïcisation et les mutations du religieux chrétien et du politique au XXème siècle”, Cristianesimo nella Storia, vol. 22, n. 3: pp. 633-657.

BEIN RICCO, Elena (2005): “Democrazia e laicità", en IDEM (ed.): Libera chiesa in libero Stato? (Turín, Editorial Claudiana) pp. 5-43.

BELLINI, Piero (2000): "II Credo de un Iaico", II Tetto, no 221: pp. 12-25.

BERGER, Peter (1971): La religión dans la conscience moderne: essai d'analyse culturelle (Traducc. Joseph FEISTHAUSER, Paris, Editions du Centurión). 287 pp.

Bernabé, Alberto y Álvarez-PedrosA, Juan Antonio (2000): "Introducción", en: IIDEM (ed.): Historia y leyes de los Hititas. Textos del Imperio Antiguo. El Código (Madrid, Ediciones Akal) pp. 9-71.

BIANCHI, Enzo (2009): "Religio civilis: profezia e laicità", en: DIONIGI, Ivano (ed.): Elogio della politica (Milán, RCS Libri S. p. A.) pp. 13-20.

BoвBı, Norberto (1986): Italia civile. Ritratti e testimonianze (Florencia, Passigli Editori). $325 \mathrm{pp}$.

BoвBıо, Norberto (1999): "Perchè non ho firmato il Manifesto laico", en: MARZO, Enzo y OCONE, Corrado (ed.): Manifesto laico (Roma-Bari, Editori Laterza) pp. 123-134.

BÖCKENFÖRDE, Ernst-Wolfgang (1991): Staat, Verfassung, Democratie: Studien zur Verfassungstheorie und zum Verfassungsrecht (Frankfurt a. Main, Editorial Suhrkamp) 443 pp.

BÖCKENFÖRDE, Ernst-Wolfgang (1992): Recht, Staat, Freheit: Studien zur Rechtsphilosophie, Staatstheorie und Verfassungsgeschichte (Frankfurt a. Main, Editorial Suhrkamp) pp. 382.

BOULADE, Gabriel (1959): "Laïcité et paix scolaire”, Esprit, vol. 27, n. 10: pp. 322-331.

BUENO, Gustavo (2008): “iDios salve la razón!”, en: PRADES, Javier (edit.), Dios salve la razón (Madrid, Ediciones Encuentro) pp. 57-92.

BuENO, Gustavo (2010): El fundamentalismo democrático. La democracia española a examen (Madrid, Ediciones Planeta). 415 pp.

BuIsson, Ferdinand (1878-1887): Dictionnaire de Pédagogie (Paris, Editorial 
Hachette)

Calvo EsPiga, Arturo (1983): "En torno a la raíz teológica del Derecho Canónico Fundamental”, Lumen, vol. 32: pp. 28-51.

Calvo Espiga, Arturo (1984): Implicaciones jurídico-canónicas de la relación entre la Iglesia y la comunidad política. Sobre el derecho de los pastores de la Iglesia para intervenir magisterialmente en asuntos políticos (Vitoria, Editorial ESET). 174 pp.

Calvo EsPIGA, Arturo (1985): "Acercamiento a la incidencia del derecho natural y de los derechos humanos en la elaboración del derecho", Scriptorium Victoriense, vol. 32: pp. 285-330.

CALVO ESPIGA, Arturo (1994): "Para una aproximación al tópico 'derechos Humanos'”, Lumen, vol. 43: pp. 69-113

Calvo Espiga, Arturo (1997): "De nuevo sobre la naturaleza y lugar del Derecho Canónico: derecho confesional 'versus' ordenamiento estatal", Scriptorium Victoriense, vol. 44: p. 58-138.

Calvo Espiga, Arturo (2001): “Conciencia y Estado de derecho", Laicidad y Libertades, vol. 1: pp. 17-45.

Calvo Espiga, Arturo (2003a): "Paradojas del pluralismo", Estudios de Deusto, vol. 51/2: pp. 93-114.

CALvo EsPIGA, Arturo (2003b): "Pluralismo, multiculturalismo y tolerancia: semántica y derecho", Scriptorium Victoriense, vol. 50: pp. 161-217.

ChInI, Paola (1990): Vita e costumi dei Romani Antichi, vol. 9. La Religione (Roma, Edizioni Quasar). 110 pp.

CoQ, Guy (2003): Laïcité et République. Le lien nécessaire (Paris, Editions du Félin). $336 \mathrm{pp}$.

Delaporte, Louis (1936): Les Hittites (Paris, Editorial La Renaissance du Livre) $371 \mathrm{pp}$.

DuguIT, Leon (1908): Le droit social, le droit individuel et la transformation de l'État: confèrences faites a l'École des Hautes Études sociales (Paris, Editions F. Alcan) pp. 154.

EDWARDS, David. y MENDus, Susan (ed.) (1987): On Toleration (Oxford, University Press). 160 pp.

FERNÁNDEZ UBIÑA, José (1982): “San Cipriano y el Imperio", Estudios Eclesiásticos, vol. 57: pp. 65-81.

GReELey, Andrew M. (1974): El hombre no secular. Persistencia de la religión (Traducc. José VAliEnTE MALLA, Madrid, Ediciones Cristiandad) pp. 301.

Guerra Gómez, Manuel (1987): El laicado masculino y femenino (Pamplona, Editorial EUNSA). $311 \mathrm{pp}$.

HABERMAS, Jürgen (2004): "Vorpolitische moralische Grundlagen eines freitheitlichen Staates", en: HABERMAS, Jurgen y RATZINGER, Joseph, Vorpolitische moralische Grundlagen eines freitheitlichen Staates (Munich, Katholische Akademie in Bayern). 72 pp.

HENNAUX, Jean-Marie (1993): Le droit de l'homme à la vie de la conception à la naissance (Bruxelles, Editorial Lessius). $198 \mathrm{pp}$.

HORTON, John y MENDUS, Susan (ed.) (1985): Aspects of Toleration (Londres, Editorial Methuen \& Co. Ltd.). 182 pp. 
JASONNI, Massimo (2009): Alle radici della laicità (Florencia, II Ponte Editore) pp. 203.

KING, Preston (1998): Toleration (Londres, Editorial Frank Cass Publishers) pp. 239.

LEVRERo, Roberta (2004): Vita e costumi nel mondo romano antico, vol. 25. II Diritto e la Giustizia (Roma, Edizioni Quasar). 166 pp.

LINDSAY, Alexander Dunlop (1934): The Churches and Democracy (Londres, Epworth Press). 87 pp.

LINDSAY, Alexander Dunlop (1942): Toleration and Democracy (Londres, Oxford University Press). $17 \mathrm{pp}$.

LOCKE, John (1689): Epistola de tolerantia (Goudae, apud Justum ab Hoeve) 96 pp. $12^{\circ}$.

Llamazares Fernández, Dionisio (1980): Derecho Canónico Fundamental (León, Editorial Colegio Universitario de León). 347 pp.

LlamaZARES FernánDez, Dionisio (2002): Derecho de la libertad de conciencia, vol. I. Libertad de conciencia y laicidad (Madrid, Editorial CIVITAS). 381 pp.

MAdDox, Graham (1996): Religion and the Rise of Democracy (Nueva York, Editorial Routledge). 392 pp.

MANCINI, Roberto (2009): La laicità come metodo (Asis, Citadella Editrice) pp. 151.

MARDONES, José María (2005): "Laicidad inteligente, democracia y religión", Diario El Correo (Bilbao, 9-10-2005) p. 37.

MENDUS, Susan (ed.) (1988): Justifying Toleration: conceptual and historical perspectives (Cambridge, Cambridge University Press). VII+260 pp.

MILTON, John (1869): Areopagitica (Londres, Editorial Edward Arber) 152 pp.

ORíGENES (2001): Contra Celsum: libri VIII, editado por MARCOVICH, Miroslav (Leiden, Editorial Brill). XXIII+637 pp.

Pigliaru, Antonio (2008): Persona umana e ordinamento giuridico (Nuevo, Edizioni il Maestrale). 203 pp.

QUeREJAZU, Javier (1994): "Perplejidades de la tolerancia", Lumen, vol. 43, n. 1-2: pp. 42-57.

Rodríguez HeRRERA, Isidoro (1978): "El hombre en Homero", Verdad y Vida, vol. 36: pp. 245-252.

ROSE, H. J. (1959): Religion in Grece and Rome (Nueva York, Editorial Harper Torchbooks). 312 pp.

SAN JUSTINO (1990): Apologías, (Traducc. Hilario YABEN, Sevilla, Editorial Apostolado Mariano). $119 \mathrm{pp}$.

SAPORETTI, Claudio (1998): Antiche leggi. I "Codici" del Vicino Oriente Antico (Milán, Editorial Rusconi). 485 pp.

SARTORI, Giovanni (2000): Pluralismo, Multiculturalismo e Estrani (Milán, Editorial RCS Libri S. p. A.). 186 pp.

SARTORI, Giovanni (2009): La democrazia in trenta lezioni (Milán, Arnoldo Mondadori Editore S. p. A.). 124 pp.

SchoOYANS, Michel (1994): "Le droit de l'homme à la vie", Nouvelle Revue Théologique, vol. 116:pp. 242-251. 
SENIK, André (2008): "Laïcité comme Laïcité (pilier de la modernité?) http://moderne.canalblog.com/archives/2008/12/13/11723431.html [Visitado el 12/1/2009].

SeuX, Marie-Joseph (1987): Lois de l'Ancien Orient (Paris, Éditions du Cerf). $112 \mathrm{pp}$.

TALBI, Michel (1991): "Les réactions non catholiques à la Déclaration du Vatican II 'Dignitatis Humanae': Point de vue musulman", en: ISTITUTO PAOLO VI, Paolo VI e il rapporto Chiesa-mondo al Concilio (Brescia) pp. 219-238.

TERTULIANO (1992): Apologeticum (Editado por RESTA BARRILE, Anna) [Bolonia, Zanichelli Editore]. 249 pp.

VERONESI, Umberto y ELKANN, Alain (2008): Essere laico (Milán, RCS Libri S. p. A.). $114 \mathrm{pp}$.

VOLTAIRE (1773): Traité sur la tolérance (Lausanne, Editorial François Grasset \& Comp.). $410 \mathrm{pp}$.

ZaGrebelsky, Gustavo (2005): Diario La Repubblica de 5 de julio de 2005. Disponible en: <http://eddyburg.it/article/articleview/3033/1/261/> [Visitado el 12/1/2009].

ZANFARINo, Antonio (1985): Pensiero político e coscienza storica (Nápoles, Edizioni Scientifiche Italiane). 208 pp.

\section{JURISPRUDENCIA CITADA}

Sentencia del Tribunal Supremo de España, 11 de febrero de 2009. Disponible en:

$<$ https://www.westlaw.es/wles/app/document?tid=jurisprudencia\&docguid=12 a589d

$8009 \mathrm{fd} 11$ de $90 \mathrm{fb} 010000000000 \&$ base-guids $=R J \backslash 2009 \backslash 1877 \& \mathrm{fexid}=$ flag-redjuris\&fexid=flag-yellow-juris\& $f$ exid $=$ flag-blue - juris\& $f$ exid=DO-ANA25\&fexid=DO-ANA-23\&srguid $=\mathrm{ia} 744900 \mathrm{c} 00000127 \mathrm{~b} 3 \mathrm{c} 5 \mathrm{f} 6 \mathrm{c} 16179 \mathrm{ebea}>$ [Visitado el 10-12-2009].

Buscarini y otros contra San Marino (1999): Tribunal Europeo de Derechos Humanos, 18 de febrero de 1999. Disponible en: $<$ https://www.westlaw.es/wles/app/document?tid=jurisprudencia\&do cguid $=19 \mathrm{~d} 14 \mathrm{a} 2 \mathrm{~d} 0 \mathrm{f} 56 \mathrm{c} 11 \mathrm{dbb}$ $564010000000000 \&$ base-guids $=$ TEDH $\backslash 1999 \backslash 4 \&$ fexid=flag - red juris\&fexid=flag-yellow-juris\&fexid=flag-blue-juris\&fexid=DO-ANA25\&fexid=DO-ANA-23\&srguid $=\mathrm{ia} 744 \mathrm{~d} 72000000127 \mathrm{~b} 3 \mathrm{~b} 8 \mathrm{a} 3 \mathrm{ad}$ 3886727d> [Visitado el 10-12-2009].

Leyla Çahin contra Turquia (2007): Tribunal Europeo de Derechos Humanos, 29 de junio de 2004. Disponible en: $<$ https://www.westlaw.es/wles/app/document? tid=jurisprudencia\&docguid $=131459120 f 76211 \mathrm{db} 9767010000000000 \&$ base guids $=$ TEDH $\backslash 2004 \backslash 46 \&$ fexid $=$ flag-red-juris \&fexid=flag-yellowjuris\&fexid=flag-blue - juris\& $f$ exid=DO-ANA-25\&fexid=DO-ANA- 


\section{3\&srguid $=i a 744 d 72000000127$}

b3c2ec5334190c26> [Visitado el 10-12-2009].

* Estudio realizado con la ayuda del Centro de Estudios anejo a la Iglesia Nacional Española en Roma.

** Licenciado y Doctor en Derecho Canónico (Univ. Pont. de Salamanca); Licenciado y Doctor en Derecho Civil (Univ. Pont. Lateranense de Roma); Licenciado y Doctor en Derecho (Univ. Complutense de Madrid); Licenciado en Teología (Univ. Pont. Gregoriana de Roma); Examen "De Universo lure Romano" (Univ. Pont. Lateranense de Roma); Abogado del Tribunal de la Rota de Roma; Catedrático de Derecho Eclesiástico del Estado (Universidad de Málaga); Correo electrónico: acalvo@uma.es.

1 Calvo (1984) pp. 51-58. Pueden verse también las siguientes publicaciones: Edwards y Mendus (1987); Horton y Mendus (1985), KING (1998); Mendus (1988). Y no podemos olvidar las quizás obras pioneras, indiscutiblemente clásicas, sobre la tolerancia: el Areopagitica de Milton (1644), la Epístola de tolerantia de Locke (1689) y el Traité sur la tolérance de Voltaire (1763).

2 Calvo (2003) pp. 161-217.

3 Probablemente el más eminente y conocido defensor de esta tesis haya sido LINDSAY (1934 y 1942), cuya postura ha sido seguida más recientemente, entre otros, por MADDox (1996) passim y por BEIN RICCO (2005) pp. 7-13.

4 SARTORI (2009) p. 48.

5 Calvo (2003a) p. 94.

6 Querejazu (1994) p. 54; TALBI (1991) p. 231.

7 Calvo (1983) p. 31; Llamazares (1980) pp. 145-171.

8 Calvo (1985) p. 292.

9 SARTORI (2000) pp. 55-60.

10 ZANFARINO (1985) p. 175.

11 Complejidad que desde la hermenéutica del estudio de los derechos de la persona, en la perspectiva de la conciencia personal, apunta LLAMAZARES (2002) pp. 46, 110-180, 204-250 y 310-314.

12 Calvo (2003b) p. 193.

13 SARTORI (2009) p. 49.

14 Para una visión comprensiva del fenómeno y del problema del pluralismo político tal como se ha venido manifestando a lo largo de la historia, así como su asunción e influencia en los ordenamientos constitucionales contemporáneos, puede verse LLAMAZARES (2002) loc. cit. en nota 11.

15 Duguit (1908), que rechaza la concepción y teoría del Estado soberano, junto con las concepciones metafísicas del derecho, puesto que, según este autor, la finalidad del Estado no ha de ser otra que la de promover la solidaridad social.

16 CALVo (2003b) p. 195-196.

17 Pagliaru (2008) p. 141-198.

18 Fernández (1982) pp. 65-66. Pueden verse también las páginas 63-65 de este mismo artículo. Bernabé y Álvarez-Pedrosa (2000) pp. 46-52 y 56-62; Chini (1990) pp. 9-88; Delaporte (1936) pp. 169-231, 241-277; LeVrero (2004) pp. 46-53; Rose (1959) pp. 65-91 y197-272; SAPORETTI (1998) pp. 21-114 y SeUX (1987) passim.

19 JASONNI (2009) pp. 17-32.

20 GUERRA (1987) pp. 21-104, así como la interesante bibliografía que ofrece en las páginas 20 y 21.

21 S. Justino, Apologeticum, I, 11, 1. Una y otra vez debieron los apologetas cristianos de explicar que el reino que ellos esperaban era, fundamentalmente, de carácter espiritual, aunque, la verdad es que con poco éxito durante mucho tiempo. Aun cuando los cristianos vivían como los paganos, según los propios escritores eclesiásticos, sin embargo, sus contemporáneos y las autoridades consideraban que no vivían como ciudadanos leales. La negativa, por ejemplo, de los cristianos a quemar unos pocos granos de incienso en las celebraciones del natalicio del emperador, debía de parecer a los paganos de tipo medio una consciente e insolente expresión de deslealtad. Los apologetas cristianos trataron de explicar que tal actitud no suponía en absoluto falta de respeto o reconocimiento hacia el símbolo nacional, ya que diariamente y con gusto elevaban sus oraciones por el emperador, 
a quien consideraban únicamente inferior a Dios, y a favor de la prosperidad de sus obras. Pero estas razones y explicaciones no resultaban eficaces ni ante las masas, ni ante la ley: el dualismo cristiano sentía ya desde sus primeros el lacero de la incomprensión. Cf. Orígenes, Contra Celsum, 8. 68-75; Tertuliano, Apologeticum, 30, 38 y 39.

22 Calvo (1994) pp. 69-113.

23 Aristóteles (1957) I, 1-2.

24 Calvo (1994) p. 89.

25 Calvo (1994) p. 89.

26 Rodríguez (1978) pp. 247-249.

27 Calvo (2001) pp. 17-45.

28 Interesante e iluminador el tratamiento, con referencias al derecho comparado y al ordenamiento español tanto ordinario como constitucional, que de la secularización y la laicidad realiza LLAMAZARES (2002) pp. 150-183, 212, 223, 232-238, 247-250, 314-322.

29 BERGER (1971) p. 174.

30 Calvo (2003b) pp. 198-203.

31 ZAGREBELSKY (2005)

32 Schooyans (1994) p. 246. Véase también Hennaux (1993) pp. 18-33.

33 AgAZZI (2000) pp. 12-17.

34 GREeley (1974) pp. 267-292.

35 Dictionnaire de Pédagogie, 1878-1887. El Diccionario de Pedagogía Ferdinand Buisson tuvo dos ediciones en 1887 y 1911. La primera es deudora del movimiento que, bajo el ministerio de Jules Ferry, condujo a la promulgación de las leyes de 1889, 1881 y 1882 en la escuela pública, laica y obligatoria. La segunda, titulada Nuevo Diccionario de Educación, presenta un resumen de la anterior y de treinta años de vigencia de las referidas leyes al tiempo que plantea el problema del método y de los métodos de enseñanza a partir de la reforma de 1902 .

36 SENIK (2008)

37 CoQ (2003) pp. 308-309.

38 Boвbio (1999) pp. 124.

39 Puede verse también, en esta línea tópica y acrítica actitud, la postura mantenida por Umberto Veronesi, médico oncólogo y ministro de sanidad en Italia (2000) con el gobierno Amato, en una extensa entrevista con Alain Elkann, origen de un pequeño libro publicado el 2008 por la Bompiani bajo el escueto y sugerente título Essere laico.

40 SENIK (2008).

41 MANCINI (2009) pp. 10-12.

42 BELLINI (2000) p. 15.

43 MANCINI (2009) pp. 111-148.

44 SENIK (2008).

45 BOULADE (1959) p. 328. También puede verse la monografía editada el año 1957 con este mismo título Laïcité et paix scolaire por la Federación Protestante de la Enseñanza, a cuyas páginas 104, 105, 106 y 107 corresponden las citas que hemos referido.

46 Bоввіо (1986) pp. 11-12.

47 Tedh, Buscarini y otros contra San Marino, 19 de febrero de 1999. Doctrina reiterada en la Leyla Çahin contra Turquia, de 10 de noviembre de 2007.

48 Calvo (1997) pp. 23-24.

49 HABERMAS (2004) p. 22.

50 HABERMAS (2004) p. 32.

51 BöCKENFÖRDE (1992) p. 112; IDEM (1991) 11-112.

52 "Stattdessen werde ich vorschlagen, die kulturelle und gesellschaftliche Säkularisierung als einen doppelten Lernprozess zu verstehen, der die Traditionen der Aufklärung ebenso wie die religiösen Lehren zur Reflexion auf ihre jeweiligen Grenzen nötigt. Im Hinblick auf postsäkulare Gesellschaften stellt sich schließlich die Frage, welche kognitiven Einstellungen und normativen Erwartungen der liberale Staat gläubigen und ungläubigen Bürgern im Umgang miteinander zumuten muss" (Ibid., p. 22).

53 "Im Gegensatz zur ethischen Enthaltsamkeit eines nachmetaphysischen Denkens, dem sich jeder generell verbindliche Begriff vom guten und exemplarischen Leben entzieht, sind in heiligen Schriften und religiösen Überlieferungen Intuitionen von Verfehlung und Erlösung, vom rettenden Ausgang aus einem als heillos erfahrenen Leben artikuliert, über Jahrtausende hinweg subtil ausbuchstabiert und hermeneutisch wachgehalten worden. 
Deshalb kann im Gemeindeleben der Religionsgemeinschaften, sofern sie nur Dogmatismus und Gewissenszwang vermeiden, etwas intakt bleiben, was andernorts verloren gegangen ist und mit dem professionellen Wissen von Experten allein auch nicht wiederhergestellt werden kann - ich meine hinreichend differenzierte Ausdrucksmöglichkeiten und Sensibilitäten für verfehltes Leben, für gesellschaftliche Pathologien, für das Misslingen individueller Lebensentwürfe und die Deformation entstellter Lebenszusammenhänge. Aus der Asymmetrie der epistemischen Ansprüche lässt sich eine Lernbereitschaft der Philosophie gegenüber der Religion begründen, und zwar nicht aus funktionalen, sondern - in Erinnerung ihrer erfolgreichen "hegelianischen" Lernprozesse - aus inhaltlichen Gründenlbid” (Ibid., p. 34).

54 Cfr. (n: 53).

55 BÖCKENFORDERT (1991) p. 111.

56 HABERMAS (2004) p. 28.

57 BUENO (2008) pp. 87-88.

58 BUENO (2008) p. 67.

59 BUENO (2008) pp. 70-71.

60 BUENO (2008) pp. 76-77.

61 BUENO (2008) pp. 78-80.

62 BUENO (2008) p. 80.

63 BUENo (2008) p. 81.

64 BUENO (2008) pp. 81-82.

65 BUENO (2008) p. 82. La cursiva es nuestra.

66 BUENO (2008) pp. 83-84.

67 BUENO (2008) p. 86.

68 BUENO (2008) p. 89.

69 BUENO (2008) p. 90.

70 BUENO (2008) p. 90.

71 BUENO (2008) pp. 91-92.

72 BAUBÉROT (2001) pp. 638-639

73 BAUBÉROT (2001) pp. 634-635.

74 Mardones (2005) p. 37.

75 BUENO (2010) pp. 159-178 y 193-320.

76 BIANCHI (2009) pp. 16-17.

77 AgAZZI (2000) pp. 10-12.

78 STS, 11 de febrero de 2009, FJ 6 y 10.

79 Arendt (1987) p. 612. 